UNIVERSIDADE DE SÃO PAULO

ESCOLA DE ENFERMAGEM

\title{
A EXPERIÊNCIA DE AMAMENTAÇÃO DE UM GRUPO DE MULHERES COM MAMOPLASTIA REDUTORA E DE AUMENTO
}

MARIA FERNANDA PELLEGRINO DA SILVA DORNAUS

SÃO PAULO

2005 
UNIVERSIDADE DE SÃO PAULO

ESCOLA DE ENFERMAGEM

\title{
A EXPERIÊNCIA DE AMAMENTAÇÃO DE UM GRUPO DE MULHERES COM MAMOPLASTIA REDUTORA E DE AUMENTO
}

\author{
Dissertação apresentada à Escola \\ de Enfermagem da Universidade de \\ São Paulo para obtenção do título de \\ Mestre em Enfermagem.
}

Orientadora: Prof. ${ }^{\text {a }}$ Dr. ${ }^{\text {a }}$ ISILIA APARECIDA SILVA

SÃO PAULO

2005 
Dornaus MFPS graduou-se em Enfermagem na Pontifícia Universidade Católica de Campinas em 1981. Obteve os títulos de Especialista em: Enfermagem Pediátrica e Puericultura no Departamento de Enfermagem da Escola Paulista de Medicina em 1982; em Administração Hospitalar e de Sistemas de Saúde na Escola de Administração de Empresas de São Paulo Fundação Getúlio Vargas e Hospital das Clínicas da Faculdade de Medicina da Universidade de São Paulo em 1983 e em Enfermagem Obstétrica no Centro Universitário Adventista de São Paulo em 2002. Certificada por International Board of Lactation Consultant Examiners, em 1998, e recertificada por exame em 2004, obtendo o título International Board Certified Lactation Consultant, Registered Lactation Consultant. Iniciou atividades profissionais no Instituto da Criança do Hospital das Clínicas da Faculdade de Medicina da Universidade de São Paulo, onde atuou por três anos e a seguir no Hospital Israelita Albert Einstein, onde atualmente desempenha a função de Coordenadora de Enfermagem da Unidade Neonatal. 


\section{Agradecimentos}

À Prof. ${ }^{a}$ Dr. $^{\text {a }}$ Isilia Aparecida Silva, pela oportunidade oferecida e valiosas orientações que muito contribuíram para a minha capacitação;

À Anna Margherita Bork e Claudia Regina Laselva, pela construção de um modelo assistencial inovador e desafiador, e por inspirar a busca de conhecimento e competência para o exercício da Enfermagem;

À Simone Maria Orsi Climeni, pelo companheirismo, incentivo e ajuda constante, durante todo 0 desenvolvimento do trabalho;

À Regina Aparecida Andrade, pela amizade e oportunidade de reflexões sobre o tema em nosso convívio profissional;

À equipe de enfermagem da Unidade Neonatal do Hospital Israelita Albert Einstein, pelo apoio e incentivo;

Ao Christian, Rafael e Victor, meus amores, pela enorme compreensão. 
Dornaus MFPS. A experiência de amamentação de um grupo de mulheres com mamoplastia redutora e de aumento. [dissertação]. São Paulo (SP): Escola de Enfermagem da USP; 2005.

As transformações sociais com a excessiva valorização da imagem corporal idealizada esteticamente, em especial das mamas como símbolo da feminilidade, submete as mulheres a procurar recursos cirúrgicos para adequar sua aparência aos padrões vigentes. A maior facilidade de acesso às cirurgias estéticas repercute na prática assistencial e observamos um número crescente de mulheres com mamoplastia. 0 objetivo deste estudo foi de compreender a experiência de amamentação de um grupo de mulheres com mamoplastia redutora e de aumento. A pesquisa qualitativa foi desenvolvida utilizando o modelo teórico representativo da experiência de amamentar, "Pesando Riscos e Benefícios", elaborado por Silva (1997), e 0 Discurso do Sujeito Coletivo (DSC) para organização dos dados. Participaram do estudo 14 mulheres, sendo oito com mamoplastia redutora e seis com implante mamário, as quais expressaram 0 desejo de amamentar e apresentavam boas condições clínicas e, mãe e recémnascido não tinham qualquer distúrbio impeditivo à amamentação. Na ocasião das entrevistas, cerca de um mês após o nascimento, no grupo de mulheres com mamoplastia redutora, a amamentação exclusiva foi observada em caráter de exceção, duas mulheres desmamaram e seis estavam em aleitamento materno. As mulheres com prótese mamária, metade estavam amamentando exclusivamente e as restantes, em aleitamento materno. $\mathrm{Na}$ análise dos dados foram extraídos 16 DSC, distribuídos em quatro temas: "Opção pela cirurgia plástica e o projeto de amamentação", "Vivenciando a prática da amamentação", "Reflexão sobre a interface da cirurgia com o processo de amamentação" e "Conciliar o papel de mãe, nutriz e mulher - não é fácil". Os DSC revelaram o movimento de mulheres em buscar a mamoplastia para obtenção de maior satisfação com a imagem corporal e as ansiedades decorrentes da opção cirúrgica que afloram na gestação ou no pós-parto ao se depararem com a prática da amamentação. Ao vivenciarem a amamentação, as mulheres avaliaram a capacidade de produzir leite em quantidade adequada às necessidades do filho. 0 complemento lácteo apareceu como benefício à mulher, sendo uma estratégia para prolongar 0 período de amamentação e postergar 0 desmame e, por vezes, como auxílio para recuperação dos traumas mamilares. As mulheres em sua maioria acreditam que a mamoplastia interferiu na amamentação, observando dificuldade de ejeção e produção láctea reduzida. As mulheres que não foram capazes de manter a amamentação exclusiva expressam sentimento de culpa pela opção cirúrgica e procuraram garantir 0 vínculo com o filho e transmitir 0 amor materno construindo outras estratégias. As dificuldades em amamentar foram pautadas em questões biológicas e estruturais da glândula mamária e não em questões culturais de valorização do corpo feminino. A crença social e dos profissionais da área da saúde que a mulher com mamoplastia não deseja amamentar, para não comprometer o resultado estético de suas mamas obtido pela cirurgia não se evidenciou. Perceber-se que permanece a intenção da mulher em manter sua imagem em concordância com os padrões idealizados, projetando a possibilidade de repetir a cirurgia no futuro. 
Dornaus MFPS. La experiencia del amamantamiento de un grupo de mujeres con mamoplastía reductora y de aumento. [dissertação]. São Paulo (SP): Escuela de Enfermería de la USP; 2005.

Las transformaciones sociales con la excesiva valorización de la imagem corporal idealizada estéticamente $y$, en especial de las mamas como símbolo de feminidad, somete a las mujeres a procurar recursos quirúrgicos para adecuar su apariencia a los patrones vigentes. La mayor facilidad de acceso a las cirugías estéticas repercute en la práctica asistencial y observamos a un número creciente de mujeres con mamoplastía. El objetivo del estudo fue comprender la experiencia de amamantamiento de un grupo de mujeres con mamoplastía reductora y de aumento. La investigación cualitativa fue desarrollada utilizando el modelo teórico representativo de la experiencia de amamantar "Pesando Riesgos y Beneficios" elaborado por Silva (1997) y para la organización de los datos el Discurso del Sujeto Colectivo (DSC). Participaron del estudio 14 mujeres de las cuales 8 con mamoplastía reductora y 6 con implante mamario, que expresaron su deseo de amamantar y que presentaban buenas condiciones clínicas y ambos, madre y recién nacido, no tenían ningún disturbio que impidieran el proceso de amamantar. Por ocasión de las entrevistas, cerca de um mes después del nacimiento, en el grupo de mujeres con mamoplastía reductora, el amamantamiento exclusivo fue observado con carácter de excepción, dos mujeres destetaron y seis estaban en lactancia materna. En las mujeres con prótesis mamaria, la mitad estaba amamantando exclusivamente y las restantes, en lactancia materna. En el análisis de los datos fueron extraídos 16 DSC, distribuídos en cuatro temas: "opción por la cirugía plástica y el proyecto de amamantamiento", "vivenciando la práctica del amamantamiento", "Reflexión sobre la interface de la cirugía con el proceso del amamamantamiento" y "conciliar el papel de madre, nutriz y mujer - no es fácil". Los DSC revelaron el movimiento de mujeres que buscan la mamoplastía para la obtención de mayor satisfacción con la imagem corporal y las ansiedades consecuentes de la opción quirúrgica que afloran en la gestación o en el post-parto al depararse con la práctica del amamantamiento. Al vivenciar el amamantamiento, las mujeres evaluaron la capacidad de producir leche en cantidad adecuada a las necesidades del hijo. El complemento lácteo apareció como beneficio para la mujer, siendo una estrategia para prolongar el período de amamantamiento y postergar el destete y, aún más, como auxilio para la recuperación de los traumas mamilares. Las mujeres en su mayoría acreditan que la mamoplastía interfirió en el amamantamiento, observando dificultad de eyección y producción láctea reducida. Las mujeres que no fueron capaces de mantener el amamantamiento exclusivo expresaron sentimiento de culpa por la opción quirúrgica y procuraron garantizar el vínculo con el hijo y transmitir el amor materno construyendo otras estratégias. Las dificultades para amamantar fueron pautadas en cuestiones biológicas y estructurales de la glándula mamaria y no en cuestiones culturales de valorización del cuerpo femenino. La creencia social y entre los profesionales del área de la salud respecto a que la mujer con mamoplastía no desea amamantar para no comprometer el resultado estético de sus mamas obtenido por la cirugía no se evidenció, a pesar de percibirse que permanece la intención de mantener su imagem en concordancia con los patrones idealizados, proyectando la posibilidad de repetir la cirugía en el futuro. 
Dornaus MFPS. The breastfeeding experience of a group of women with reducing and enlarging mammoplasty. [dissertation]. São Paulo (SP): Escola de Enfermagem da USP; 2005 [USP Nursing School]

The social transformations with excessive valuation of the aesthetically idealized body image and, specially the breasts as femininity, submit the women to search surgical resources in order to adequate their appearance to the present patterns. The bigger easiness of access to the aesthetical surgeries reverberates on the first-aid practice and we observe an increasing number of women with mammoplasty. The object of present study was to understand the breastfeeding experience of a group of women with reducing and enlarging mammoplasty. The qualitative research was developed utilizing the representative theoretical model of the breastfeeding experience "Pesando Riscos e Benefícios" [Weighing Risks and Benefits] elaborated by Silva (1997) and for the data organization the Discurso do Sujeito Coletivo (DSC) [Collective Subject Speech]. It has participated in the study 14 Women being 8 with reducing mammoplasty and 6 with mammary implant, that expressed the desire for breastfeeding and that presented good clinical conditions and both, mother and newborn, did not have any impeditive disturbance to the breastfeeding. By the occasion of the interviews, about one month after the birth, in the group of women with reducing mamoplasty, the exclusive breastfeeding was observed in exception character, two women have weaned and six were in maternal feeding. On the women with mammary prosthesis, half of them was exclusively breastfeeding and the remaining, on maternal feeding. In the data analysis there were drawn 16 DSCs, distributed in four themes: "Option for the plastic surgery and the breastfeeding project", "Experiencing the breastfeeding practice", "Reflection about the surgery interface with the breastfeeding process" and "Conciliating the mother, nourisher and woman role - it is not easy". The DSCs have disclosed the women motion searching the mammoplasty for achieving greater satisfaction with the body image and the anxieties elapsing from the surgical option that arise on the gravidity or on the post-partum when facing with the breastfeeding practice. When experiencing the breastfeeding, the women have assessed the capacity for producing milk in a quantity adequate to the child necessities. The lactic complement has shown up as a benefit for the woman, being a strategy for extending the breastfeeding period and postponing the weaning and, many times, as a help for recovering from the mammilary traumas. Most of the women believe that the mammoplasty has interfered in the breastfeeding, observing ejection difficulty and reduced lactic production. The women that were not capable of sustaining the exclusive breastfeeding expressed guilty sense for the surgical option and tried to ensure the entailment with the child and to transmit the maternal love building new strategies. The difficulties for breastfeeding were guided by biological and structural questions of the mammary gland and not by cultural questions of female body valuation. The social belief and among the professionals of the area that the woman with mammoplasty do not desire to breastfeed in order to not compromise the static results of her breasts achieved through surgery has not been shown clearly, although being perceived that it remains the intention for keeping her image according to the idealized patterns, projecting the possibility for repeating the surgery in the future. 
SUMÁRIO

RESUMO

ABSTRACT

I. INTRODUÇÃO

II. BASES TEÓRICAS E METODOLÓGICAS

III. DESCRIÇÃO DA PESQUISA

IV. OS DISCURSOS REPRESENTATIVOS DAS EXPERIÊNCIAS DAS MULHERES

V. CONSIDERAÇÕES FINAIS

REFERÊNCIAS BIBLIOGRÁFICAS 


\section{INTRODUÇÃO}

O conceito de beleza do corpo sofreu variações de acordo com cada época e cultura, mas as mamas sempre estiveram em evidência por caracterizar a condição de mulher e representar a expressão da sexualidade feminina. Pinturas e esculturas do período clássico representam a beleza feminina com formas arredondadas, quase obesas e com seios volumosos. A partir do último século, as mamas mantiveram-se relacionadas ao padrão de beleza da mulher e continuam sendo consideradas como um atrativo sexual, embora nas últimas décadas tenham sido associadas a um corpo esguio (Aboudib Junior et al., 1991).

Atualmente nos deparamos com um fenômeno social que consiste na submissão da mulher a padrões estéticos que definem seu valor e inserção social. O valor feminino continua a ser ditado por uma ordem masculina que legitima a importância da beleza e estabelece o padrão vigente focado na juventude e sedução. Esse modelo impulsiona a mulher a procurar por diversos recursos tecnológicos e cosméticos para embelezamento, incluindo as cirurgias plásticas para reconstrução do corpo e de sua imagem a fim de conquistar o máximo de sensualidade e reconhecimento social. Um novo ciclo histórico sustentado na industrialização da beleza difunde amplamente as normas e ideais estéticos em que as mulheres são as maiores consumidoras deste novo mercado (Reis, 2002).

Com o desenvolvimento da indústria cosmética, a conjugação da beleza da mulher e consumo se expandiu por meio das revistas femininas. Prosperaram lançamentos de novos títulos que exaltam os cuidados com o corpo associados com 0 alcance da felicidade. Ser bela tornou-se uma obrigação do gênero feminino (Reis, 2002). 
Neste cenário, a inquietação com a aparência afeta as mulheres de forma significativa e, embora nos últimos anos tenha havido um aumento da preocupação masculina, ainda existe uma diferenciação entre os gêneros em relação ao valor atribuído a imagem corporal. Bordo (1997) salienta que as mulheres são convertidas em pessoas orientadas à automodificação por meio de disciplinas reguladoras sobre a dieta, maquiagem e vestuário, consumindo muito mais tempo na disciplina de seus corpos na busca de um ideal de feminilidade em constante mutação. Isso exige que sigam mudanças extravagantes e insignificantes da moda transmitidas culturalmente por meio de imagens visuais no cinema, na televisão e na mídia em geral.

A beleza feminina consagra-se como um forte argumento publicitário. Enquanto, no século passado, nas décadas de 30 a 50, existia uma relação do produto com 0 universo feminino, a partir da década de 60, a mulher transformou-se em objeto publicitário para vender qualquer que seja o bem ou serviço (Reis, 2002). Mulheres perfeitas, com seios volumosos, aparecem constantemente na mídia e raramente nos deparamos com imagens realísticas mesmo em materiais educativos na área da saúde. Esse padrão pressiona a mulher a adquirir uma melhor imagem corporal, uma vez que dificulta a compreensão e aceitação da sua própria aparência pessoal (Smith, Kent, 2002).

A fim de realçar as mamas, as mulheres empregam diversos métodos não cirúrgicos, como enchimentos e sutiãs especiais. Embora sejam recursos seguros e de baixo custo, nem sempre são considerados como opções satisfatórias, pois, o efeito é transitório e muitas mulheres recorrem a cirurgias plásticas por sentirem-se sexualmente inibidas e pouco femininas (Smith, Kent, 2002).

A maior procura de cirurgias plásticas está associada à crescente divulgação dos procedimentos estéticos na imprensa leiga (Ribeiro et al., 1992). Um assunto bastante explorado 
na imprensa é a "construção da beleza" com a exposição prévia e posterior exibição dos resultados cirúrgicos daqueles que remodelam a aparência (Reis, 2002). A influência estrangeira no padrão do tamanho das mamas, o vestuário moderno e a divulgação das formas do corpo são fatores citados por Abla (2002). A redução de custos, a facilidade de acesso e a aceitação destes procedimentos contribuem para um maior número de cirurgias estéticas.

A cirurgia estética é, em geral, definida como aquela indicada para corrigir alterações fisiológicas da anatomia externa, para conquistar a harmonia do corpo e justifica-se pelos benefícios psicológicos e satisfação do paciente. Após a cirurgia foram identificadas as melhoras de sentimentos de inadequação social, insegurança e ansiedade (Ribeiro et al., 1992).

O desejo em alterar o tamanho das mamas é complexo e envolve questões pessoais, sociais, culturais e psicológicas (Smith, Kent, 2002). Abla (2002) afirma que, embora a psicoterapia possibilita ajudar a melhorar a satisfação com a imagem corporal, somente a cirurgia é capaz de trazer benefícios objetivos neste aspecto, sendo o recurso mais eficaz para melhorar a percepção negativa das pacientes em relação às suas mamas.

Ao pesquisar o motivo da procura da mamoplastia redutora, encontramos trabalho conduzido por Ribeiro et al. (1992) com 53 pacientes para avaliar as motivações, expectativas e características de personalidade das mulheres que desejavam ser submetida à cirurgia. As pacientes eram jovens, com um ou sem filhos. Estavam insatisfeitas com o corpo e relatavam timidez, vergonha e insegurança. A principal motivação para cirurgia foi obtenção da satisfação pessoal (45\%). Os autores constataram que as mulheres apresentavam necessidade de sentirem-se atraentes e valorizadas. Os pesquisadores comentam ainda que as participantes do estudo estavam determinadas a ir contra os preceitos sociais, pois nas décadas anteriores as 
mulheres aguardavam a realização da função materna de parir e amamentar, retardando as questões de satisfação pessoal.

Young, Nemecek, Nemecek (1994) desenvolveram um estudo com 112 mulheres para avaliar o aumento do tamanho das mamas após a inserção de prótese. Em média houve aumento de dois números de sutiã no tamanho do bojo ou do mesmo associado à circunferência torácica. As pacientes foram questionadas quanto ao impacto da cirurgia em aspectos emocionais. Este grupo de mulheres reportou diminuição da ansiedade (86\%), aumento da confiança (88\%) e 95\% referiram sentir-se melhor consigo mesmas após a cirurgia. A satisfação com o resultado cirúrgico foi elevada, $86 \%$ referiram que a cirurgia foi um completo sucesso e 95\% expressaram ter atendido as expectativas. Responderam que repetiriam a cirurgia $81 \%$ das mulheres. Cerca de 14\% das mulheres expressaram voluntariamente melhora na saúde mental.

Abla (2002) avaliou as possíveis mudanças decorrentes da mastoplastia de aumento na qualidade de vida e na auto-estima de 40 mulheres com hipomastia. As pacientes eram eutróficas, jovens, solteiras (65\%), com nível de escolaridade superior ou médio e 55\% exerciam atividade extradomiciliar remunerada. Cerca de $37,5 \%$ das pacientes tinham filho. A mastoplastia de aumento promoveu mudanças positivas na auto-estima e na qualidade de vida das pacientes. Em relação à capacidade funcional, as mulheres relataram ter voltado completamente às atividades diárias, sentiam-se confortáveis e seguras com o tamanho atual de suas mamas. Referiram não se preocupar tanto com a aparência e relataram ter mais disposição para as tarefas diárias e melhor desempenho nas atividades profissionais. Nos aspectos sociais, emocionais e de saúde mental houve melhora significante com diminuição da ansiedade após a cirurgia. 
Sarwer et al. (1998) investigaram o nível de satisfação em relação à imagem corporal das mulheres que desejavam submeter-se à mamoplastia redutora ou de aumento. Ambas as amostras de 30 mulheres reportaram grande insatisfação com a imagem corporal com alterações comportamentais significativas. Cerca de $60 \%$ das pacientes, para mamoplastia redutora e $53 \%$ das pacientes para mamoplastia de aumento, referiram checar a aparência das mamas mais de $50 \%$ dos dias do mês. Mais de $50 \%$ de ambos os grupos relataram que evitavam ser vistas sem roupas por outros e mais de $60 \%$ de ambos os grupos informaram camuflar as mamas com roupas e sutiãs especiais mais da metade dos dias do mês. Candidatas à mamoplastia redutora (43\%) e de aumento (40\%) reportaram comparar a aparência de suas mamas com as de mulheres de seu círculo social e com aquelas que aparecem na mídia.

Em relação à satisfação das mulheres com o resultado cirúrgico da mamoplastia redutora, Aboudib Junior et al. (1991) constataram que 92\% delas estavam satisfeitas com os resultados da cirurgia.

Assim, é possível perceber que a valorização da imagem corporal das mulheres, idealizada esteticamente, vem consolidando, ao longo do tempo, em especial as mamas, como símbolo de feminilidade. As questões de insatisfação pessoal com a auto-imagem e a pressão social para atingir um ideal de beleza e sensualidade têm conduzido adolescentes e mulheres de todas as faixas etárias a buscar auxílio cirúrgico para atingir seu ideal de beleza e satisfação com o corpo. Em virtude desse fato, sendo causa ou conseqüência, as técnicas cirúrgicas também sofreram avanços significativos, oferecendo acesso e certa segurança para as mulheres, a depender do objetivo que estas desejam atingir. 


\section{Mamoplastia redutora}

Mulheres que desejam diminuir o tamanho das mamas recorrem à mamoplastia redutora. A cirurgia é indicada nos casos de macromastia a fim de aliviar sintomas físicos, problemas funcionais e emocionais significativos causados pelo tamanho e peso excessivo das mamas (Black, 1997; Mohrbacher, Stock, 1997; Greenfield, 2001; Franco, 2002; Smith, Kent, 2002).

Os sintomas físicos da macromastia incluem dor na mama, ombros, pescoço e costas, cefaléia e lesões na pele (Greenfield, 2001; Smith, Kent, 2002). Apesar do uso de sutiã, a sustentação das mamas hipertróficas é pouco eficiente e o peso excessivo provoca dor nos ombros e sensação de cansaço. Em alguns casos, as mulheres apresentam sulcos profundos nos ombros decorrentes da tração exercida pelo peso das mamas com as alças do sutiã (Smeltzer, Bare, 2002).

Limitações de atividades diárias e recreativas são descritas devido ao desconforto físico. O desejo de evitar exposição social além da dificuldade em obter sutiã e roupas adequadas são fatores que dificultam a prática de esportes (Sarwer et al., 1998; Greenfield, 2001; Smith, Kent, 2002; Smeltzer, Bare, 2002). Conseqüências emocionais incluem insegurança, vergonha sobre 0 tamanho das mamas, insatisfação com a imagem corporal e embaraço em atividades sociais (Sarwer et al., 1998; Smith, Kent, 2002; Smeltzer, Bare, 2002).

A cirurgia consiste em ressecção do tecido mamário e pele seguida de reposicionamento do complexo mamilo-areolar. São descritas variações do procedimento cirúrgico com diversidades no tipo de incisão, técnica de ressecção de tecido mamário, construção de retalhos de tecido para projeção do cone mamário e posicionamento do complexo mamilo areolar (Black, 1997; Greenfield, 2001; Franco, 2002; Smith, Kent, 2002). A eleição da técnica depende do tamanho e consistência da mama e quantidade de tecido a ser ressecado (Franco, 2002). 
A possibilidade de aleitamento tem relação inversa e proporcional à quantidade de tecido mamário ressecado, isto é, quanto maior a quantidade de tecido mamário removido, menor é a possibilidade de aleitamento (Black, 1997; Mohrbacher, Stock, 1997).

$\mathrm{Na}$ mamoplastia redutora há duas variações técnicas para o posicionamento do complexo mamilo-areolar. Na técnica de transposição são mantidas as conexões vasculares e nervosas com o tecido subjacente por meio de um pedículo do parênquima mamário e após a ressecção e modelagem da mama, o complexo mamilo-areolar é situado alguns centímetros acima da posição anterior. Na técnica de ressecção do mamilo ou enxertia, o complexo mamiloareolar é ressecado, conservado em soro durante 0 ato cirúrgico e após a modelagem da mama é implantado (Black, 1997; Berens, 2001; Franco, 2002).

Ao considerar o impacto da cirurgia na amamentação, a técnica de transposição do complexo mamilo-areolar tem sobre a enxertia vantagens funcionais. A manutenção do complexo mamilo-areolar ligado a um pedículo do parênquima mamário conserva as conexões vasculares e nervosas e dessa forma preserva a sensibilidade tátil e a contratilidade (Marshal, Callan, Nicholson, 1994; Johnson, Preuss, Eriksson, 2001; Greenfield, 2001; Franco, 2002). Os ductos lactófaros não seccionados permitem a lactação (Marshal, Callan, Nicholson, 1994; Franco, 2002). Embora alguns cirurgiões acreditem que todo o tecido mamário que permanece conectado ao mamilo possibilita a lactação, em especial a ejeção do leite, Mohrbacher, Stock (1997) e Smith, Kent (2002) destacam que os ductos são freqüentemente cortados na cirurgia e 0 aleitamento pode não ser possível. Sugerem alertar as mulheres que consideram a mamoplastia redutora e discutir a possibilidade de adiar a decisão da plástica até após o nascimento dos filhos, já que a mama também altera com a progressão da gestação e pode interferir no resultado cosmético do procedimento. 
A técnica de ressecção do mamilo tem a desvantagem de reduzir significativamente a sensibilidade da região mamilo-areolar e a capacidade de lactação, pois todos os ductos e enervações são seccionados (Black,1997; Mohrbacher, Stock, 1997; Johnson, Preuss, Eriksson, 2001; Berens, 2001). Apesar da produção de leite nas celulares alveolares, este não alcança os poros mamilares, pois todos os ductos foram cortados. Foram reportados casos de ductos recanalizados espontaneamente e que possibilitaram a saída do leite (Black, 1997; Mohrbacher, Stock, 1997)

As complicações cirúrgicas da mamoplastia redutora incluem deiscências, cicatrizes hipertróficas ou anti-estéticas, retardo no processo de cicatrização, infecção, assimetria da mama, perda e alteração da sensibilidade do complexo mamilo-areolar (Greenfield, 2001; Franco, 2002; Smith, Kent, 2002). Alterações sensoriais como dormência desaparecem depois de alguns meses, embora possa ocorrer persistente diminuição da sensibilidade nos mamilos (Smeltzer, Bare, 2002).

Franco (2002) conduziu estudo sobre a sensibilidade na região mamilo-areolar em pacientes submetidas à mamoplastia redutora comparando com mulheres não operadas. No último grupo foi observada insensibilidade em $17 \%$. Nas pacientes operadas com técnica de transposição, houve perda de sensibilidade do mamilo em $30 \%$. Na técnica de enxertia foram observados casos de manutenção de sensibilidade e de contratilidade mamilar em apenas $20 \%$.

A secção das enervações, durante a cirurgia, reduz a sensibilidade do complexo mamiloareolar em graus variáveis. O estímulo das terminações nervosas da região mamilo-areolar pela sucção do lactente é conduzido à hipófise para a liberação de prolactina e ocitocina, hormônios necessários para a produção e ejeção do leite materno e manutenção da lactação. A ausência da 
sensibilidade interfere na condução do estímulo e conseqüentemente na produção e ejeção láctea e continuidade da amamentação (Marshall, Callan, Nicholson, 1994).

Mulheres com história de mamoplastia redutora na juventude freqüentemente relatam que foram alertadas a adiar a plástica, considerando que a amamentação poderia não ser possível, mas esse aspecto não foi julgado importante na época da cirurgia (Marshal, Callan, Nicholson, 1994).

\section{Mastoplastia de aumento}

Mulheres que desejam aumentar o tamanho das mamas a fim de conquistar uma melhor imagem corporal recorrem à implantação de próteses. A cirurgia possibilita reconstruir as mamas das pacientes submetidas à mastectomia, corrigir deformidades anatômicas e aumentar 0 tamanho das mamas quando as mesmas são consideradas pequenas em proporção ao tamanho do corpo (Rohrich, Muzaffar, 2000; Johnson, Preuss, Eriksson, 2001; Smith, Kent, 2002).

As próteses mamárias são utilizadas desde 1962 com cerca de 150.000 implantes a cada ano apenas nos Estados Unidos, sendo 60-80\% para aumento do volume mamário e 20-40\% para reconstrução da mama pós-mastectomia (Berlin, 1994; Hurst, 1996; Jordan, Blum, 1996; Fine, Mustoe, Fenner, 2000; Rohrich, Muzaffar, 2000). A inserção de prótese de mama é a segunda mais freqüente cirurgia plástica nos Estados Unidos, onde se estima que um a dois milhões de mulheres submeteram-se a esse procedimento (Young, Nemecek, Nemecek, 1994; Hurst, 1996; Jordan, Blum, 1996; Mohrbacher, Stock, 1997; Kopans, 2000; Rohrich, Muzaffar, 2000; Smith, Kent, 2002).

A prótese mamária é inserida por meio de uma incisão pequena, submamária, periareolar, transareolar, axilar ou transumbilical e posicionada sob o músculo peitoral, técnica 
relacionada com menor incidência de contratura, ou alocada sobre o músculo peitoral diretamente abaixo da glândula mamária. A orientação pré-cirúrgica deve incluir tamanho e forma do implante, tipo de anestesia, método de inserção e possíveis complicações, como infecção, hematoma, dor, alterações de sensibilidade do mamilo, contratura capsular e impacto no exame de detecção de câncer (Johnson, Preuss, Eriksson, 2001; Smith, Kent, 2002).

A complicação mais freqüente à implantação da prótese de mama e de ocorrência tardia é a contratura capsular, encontrada em $15 \%$ dos casos. A maioria dos implantes estimula os miofibroblastos a formarem uma cápsula fibrosa ao redor da prótese. Esta cápsula pode contrair causando dor e a sensação que o implante está duro ou rompido (Kopans, 2000; Smith, Kent, 2002). Em 10 a 40\% das pacientes, a contratura desta cápsula resulta em endurecimento e deformidade da mama com necessidade de capsulotomia ou remoção do implante (Sclnitt, Connolly, 2000).

Outra complicação cirúrgica tardia é a ruptura dos implantes, intra ou extracapsular, que ocorre em 3,9\% dos casos. A ruptura intracapsular é definida como a ruptura do invólucro do implante, mas o gel continua contido na cápsula fibrosa formada pelo organismo. A cápsula fibrosa pode não ser contínua e neste caso a parte do implante protrai, resultando em uma herniação. Quando tanto o invólucro do implante como a cápsula fibrosa estão rompidos há extravasamento de silicone nos tecidos, denominado ruptura extracapsular (Kopans, 2000). Nos casos de rompimento da prótese, a mama pode apresentar nódulos, alterações de formato, tamanho e aumento da sensibilidade (Smith, Kent, 2002).

Questões relativas a vazamentos e a presença de silicone no organismo conduziram a pesquisas cujos resultados não são conclusivos. Quando detectada a presença de silicone em um organismo não é possível determinar sua origem, se proveniente da prótese ou de outra 
fonte, devido à elevada freqüência desse elemento no meio ambiente. O silicone é o segundo elemento mais freqüente no planeta, sendo encontrado na água, fórmulas lácteas infantis, alimentos industrializados, cosméticos, medicamentos, bicos de mamadeiras e chupetas (Berlin, 1994; Jordan, Blum, 1996; Mohrbacher, Stock, 1997; Rohrich, Muzaffar, 2000). O silicone também é usado em grande variedade de produtos médicos como cateteres venosos, sondas, válvulas cardíacas e implantes articulares sem relatos associados de distúrbios clínicos (Fine, Mustoe, Fenner, 2000; Rohrich, Muzaffar, 2000).

Além das complicações locais relacionadas ao procedimento cirúrgico e a presença da prótese, o desenvolvimento de distúrbios clínicos na mulher e no seu filho foram objetos de estudo de alguns pesquisadores. Patologias diversas na mulher, como doença reumática, esclerodermia, lúpus eritematoso sistêmico e doença do tecido conjuntivo foram sugeridas em diversos trabalhos, mas não há pesquisas prospectivas que confirmem esses achados e o risco para doenças auto-imunes (Jordan, Blum, 1996; Fine, Mustoe, Fenner, 2000).

Outros pesquisadores investigaram o desenvolvimento de distúrbios auto-imunes nos filhos de mulheres com próteses de silicone. Foi considerada a possibilidade de desprendimento de micropartículas de silicone da prótese, as quais, circulantes na corrente sanguínea, atingiriam o feto por via transplacentária. O leite materno também poderia transmitir essas partículas desprendidas que seriam absorvidas pelo trato gastrintestinal do lactente, desencadeando patologias (Berlin, 1994; Jordan, Blum, 1996). Os estudos não confirmaram essas hipóteses.

O Comitê de Drogas da Academia Americana de Pediatria, em sua última revisão referente à transferência de drogas e outras substâncias químicas no leite humano, declarou que a presença da prótese de silicone não constitui uma contra-indicação ao aleitamento materno. Não há evidências até o momento que o polímero de silicone é diretamente tóxico aos tecidos 
humanos, embora existam preocupações quanto a desencadear mecanismos imunológicos, os quais ainda não foram confirmadas em estudos humanos. Foram poucas as ocasiões que os polímeros foram identificados no leite de mulheres com implantes e a concentração não era elevada nas amostras. É pouco provável que o silicone possa causar danos porque está presente em uma concentração muito mais elevada no leite de vaca do que no leite de mulheres com prótese de silicone (American Academy of Pediatrics, 2001).

Freqüentes questionamentos sobre a segurança das próteses de mama com associação a distúrbios auto-imunes e o número crescente de ações litigiosas implicaram na suspensão das vendas de implantes de silicone nos Estados Unidos pela organização "Food and Drug Administration". Apenas implantes com conteúdo salino são permitidos para cirurgias estéticas de aumento mamário naquele país desde 1992 (Berlin, 1994; Jordan, Blum, 1996; Kopans, 2000; Fine, Mustoe, Fenner, 2000; Rohrich, Muzaffar, 2000; Smith, Kent, 2002). O uso de prótese de silicone tornou-se pouco freqüente e associado com mamoplastia reconstrutora pós-mastectomia e para um grupo restrito de mulheres incluídas em estudos científicos (Rohrich, Muzaffar, 2000; Smith, Kent, 2002). No Brasil a legislação não faz restrição ao uso de prótese de silicone e é 0 material de escolha para implantação.

Podemos considerar que as próteses mamárias podem ocasionar dificuldades na amamentação decorrentes da manipulação da mama em graus variáveis para inserção do implante no ato cirúrgico. As incisões periareolar e transareolar apresentam maior potencial para lesar os ductos, diminuir a inervação e reduzir a sensibilidade mamilo-areolar (Hurst, 1996; Mohrbacher, Stock, 1997; Berens, 2001). Na técnica cirúrgica, em que a prótese é inserida via axilar, também há risco de lesão do nervo intercostal no ato operatório e ocasionar alterações na sensibilidade da mama (Hurst, 1996). Podemos inferir que a presença de aderências e fibroses 
no complexo mamilo-areolar, decorrentes da cicatriz cirúrgica, pode reduzir a elasticidade dos tecidos e dificultar a sucção do recém-nascido, além dos efeitos da diminuição da sensibilidade dessa região, condições estas que dificultam o estímulo da região mamilo-areolar e podem estar associadas à redução da produção láctea.

A inserção de uma prótese além de impelir a mama para frente também comprime 0 parênquima e o grau de compressão está relacionado com o tamanho do implante (Young, Nemecek, Nemecek, 1994). Na apojadura, a compressão provocada pela prótese na glândula mamaria ocasiona dor e pode dificultar a ejeção do leite.

Hurst (1996) pondera que a pressão exercida pelo implante pode ser prejudicial à produção de leite. $\mathrm{O}$ aumento da pressão intramamária quando ocorre de forma contínua e prolongada pode causar atrofia das células das paredes dos alvéolos e diminuir a produção de leite. Questiona se 0 implante mamário subglandular pode ser mais prejudicial à produção de leite em decorrência do contato direto e da pressão do mesmo na glândula mamária.

Complicações pós-operatórias decorrentes do procedimento de implante mamário, como hematomas, encapsulamento, infecções locais e necrose do mamilo são fatores que podem aumentar o risco de insucesso do aleitamento materno por lesar o parênquima mamário.

Thompson (2002) relata que muitas mulheres e familiares têm dúvidas relacionadas à presença de implantes de silicone na mama no início da amamentação. Mulheres submetidas a essa cirurgia demonstram insegurança com a amamentação e preocupação com os aspectos estéticos.

Hurst (2003) recomenda que todas as mulheres que planejam amamentar devem ter histórico sobre cirurgias mamárias investigado, incluindo tipo de cirurgia e data, local da incisão para implantação da prótese, complicações cirúrgicas, tais como alterações na sensibilidade do 
mamilo, contraturas e se houve necessidade de novos procedimentos como capsulotomia, remoção ou reposição do implante. Refere que essas questões proporcionam um panorama do parênquima mamário após o procedimento cirúrgico. Hurst sugere acompanhamento para observar sinais de adequada ingestão de leite e crescimento do recém-nascido nas primeiras semanas pós-parto de forma a possibilitar intervenção quando necessária.

Embora existam diferenças técnicas entre a mamoplastia redutora e a de aumento, mesmo em um único tipo de cirurgia, há opções para condução do procedimento cirúrgico. $\mathrm{Na}$ prática clínica, observamos que mulheres com mamoplastias, em geral, vivenciam dificuldades para aleitar em graus variáveis o que nos leva a considerar as implicações dessas cirurgias no processo do aleitamento materno.

\section{Implicações das mastoplastias no processo de aleitamento materno}

Embora possamos considerar que os procedimentos cirúrgicos para transformação estética das mamas sejam recentes, do ponto de vista da ciência e da história, há poucos estudos desenvolvidos avaliando o impacto das mamoplastias redutoras na lactogênese e amamentação de um modo geral, bem como, também são escassas as pesquisas sobre a relação das inserções de próteses mamárias e 0 aleitamento materno.

Entre os estudos que correlacionam cirurgias mamárias e a produção láctea, temos 0 trabalho de Aboudib Junior et al. (1991) desenvolvido com 50 mulheres submetidas à mamoplastia redutora. Desse grupo, 22\% engravidaram após a cirurgia. Cerca de $81.81 \%$ das mulheres que engravidaram referiram lactação e amamentação normal e satisfação com resultado cirúrgico. Cerca de 18,19\% das mulheres reportaram diminuição da produção láctea e não amamentaram. Cerca de $12 \%$ do total das mulheres submetidas à mamoplastia referiram 
redução de sensibilidade mamilo-areolar com variações de intensidade. No entanto, os resultados desse estudo não nos esclarecem muito sobre a interferência dos procedimentos aos quais as mulheres foram submetidas, uma vez que os autores não definiram o que consideram como amamentação normal. Também, não avaliaram o tempo de amamentação e se houve necessidade de complementação da dieta do recém-nascido.

Marshall, Callan, Nicholson (1994) conduziram estudo com 30 mulheres submetidas à mamoplastia redutora no período de 1988-1990. Cerca de 93\% tinham intenção de amamentar, sendo que $73 \%$ estavam amamentando na ocasião da alta. Após três meses, 27\% amamentavam e apenas uma sem necessidade de complementação alimentar. No grupo controle ( $n=349$ ), 90\% das mulheres desejavam amamentar, 54\% estavam amamentando após três meses do parto, sendo 47\% exclusivamente.

Johansson et al. (2003) ao examinarem a literatura referente aos índices de amamentação após procedimentos cirúrgicos mamários, encontraram variações na freqüência de mulheres que amamentaram após mamoplastia redutora entre 19 a 82\% e entre 36 a 85\% após implantação de próteses. Destaca a impossibilidade de comparação entre os estudos devido ao número reduzido das amostras e das diferentes técnicas do procedimento que podem interferir no resultado. A definição do tipo de aleitamento e o período de amamentação não são uniformes entre os estudos.

Hurst (1996) conduziu um estudo retrospectivo comparando o resultado da lactação de 42 mulheres com prótese mamária e 42 mulheres sem. Nas mulheres com implantes foi encontrada uma significativa maior incidência de lactação insuficiente. A lactação insuficiente foi de 64\% nas mulheres com implante e de 3\% nas sem implante. 0 tipo de incisão cirúrgica estava 
significativamente associado com o resultado da lactação e a abordagem periareolar com lactação insuficiente.

No manejo clínico do aleitamento materno, o motivo da mamoplastia deve ser pesquisado. Embora em geral a cirurgia seja indicada por razões estéticas, há possibilidade de ser decorrente da reconstrução mamária após ressecção de massa cancerígena. Em todos os casos de cirurgia mamária é importante a avaliação e o acompanhamento do recém-nascido durante o período de amamentação, pois o risco de insucesso no aleitamento materno ainda não foi suficientemente esclarecido por pesquisas científicas.

Na minha vivência profissional, como coordenadora de enfermagem em uma unidade neonatal de um hospital privado, com clientes de condição socioeconômica e nível de escolaridade elevado, tenho como uma das propostas de trabalho capacitar a equipe a prestar atendimento à mulher, considerando seu contexto cultural e social, e favorecer a prática da amamentação para aquelas que desejam amamentar. Dessa forma, busco meu desenvolvimento e da equipe de enfermagem em relação ao manejo do aleitamento materno.

Contamos na literatura com diversos trabalhos científicos sobre amamentação os quais fundamentam a nossa prática assistencial e dispomos de inúmeros estudos que abordam aspectos biológicos e técnicos da amamentação e desmame. Encontramos, também, estudos que abordam com maior amplitude outras questões relativas à amamentação, com foco na experiência de amamentar das mulheres, além dos aspetos biológicos dessa prática, como os de Arantes (1991), Silva (1997), Nakano (1996), Almeida (1999), Masson (2002), entre outros. Esse corpo de conhecimento tem sido importante para abranger a maioria das dificuldades vivenciadas pelas nutrizes em nossa prática diária, ao longo dos últimos anos, e nos dar subsídios para desenvolver o atual protocolo de assistência em aleitamento materno. 
No entanto, atualmente, com o culto de valorização e embelezamento do corpo com recursos cosméticos e cirúrgicos, temos nos deparado com um número crescente de nutrizes com mamoplastias de aumento e redutoras, assistidas na maternidade em seu processo de gestação, parto e puerpério.

Essas mulheres que recorreram à cirurgia plástica, durante a adolescência ou quando adultas jovens, em geral, relatam que estavam descontentes com suas mamas e que 0 procedimento foi realizado em uma fase de suas vidas, que precedeu questões de constituição familiar e geração de filhos.

É comum sermos abordadas por essas mulheres no decorrer da gestação e no puerpério, para esclarecimento de suas dúvidas, já no curso de preparação para o parto, bem como no pós-parto quando se deparam com a vivência de aleitar o filho. Comumente direcionam suas indagações aos profissionais de saúde que as assistem durante o período de internação hospitalar, no intuito de obter orientações e auxílio efetivo.

A literatura científica sobre amamentação com mulheres submetidas à mamoplastia é reduzida, como já comentado anteriormente, poucos trabalhos científicos estão disponíveis para direcionar os profissionais nessa prática assistencial.

$\mathrm{Na}$ área de enfermagem, em que corpo profissional abraçou a assistência às mulheres com intuito de incentivar a amamentação, dispomos de muitas pesquisas, entretanto não encontramos estudo sobre 0 aleitamento de mulheres que se submeteram à mamoplastia. Muitas vezes não encontramos respostas para as dúvidas dessas mulheres e nos faltam elementos para o planejamento da sua assistência.

Em anos anteriores, a aceitação e o número de cirurgias plásticas não eram tão significativos visto que havia um menor número de mulheres que se submetia a essa cirurgia. 
Os trabalhos publicados que relacionaram mastoplastia e aleitamento enfocam apenas os fenômenos biológicos associados a tempo de amamentação e a produção láctea a despeito das questões estéticas e ansiedades dessas nutrizes. Observamos que muitas mulheres apresentam-se ansiosas sobre suas possibilidade de amamentação. Relatam que no momento que buscaram a cirurgia plástica essa questão não foi considerada ou não era prioritária na decisão cirúrgica, justificando o desconhecimento sobre a implicação na amamentação. Apenas no momento da gestação é que a amamentação foi ponderada, acarretando ansiedade quanto à incapacidade em aleitar e prejuízo à saúde do bebê.

A mulher que se submeteu à cirurgia plástica mamária em geral estava insatisfeita com suas mamas e valoriza sua imagem. Questionamos se as mulheres com mamoplastia priorizam a imagem corporal e em especial as mamas ao tomar decisões quanto à implementação e continuidade do aleitamento.

O receio que a prática do aleitamento possa ter interferência na forma das mamas, anulando o resultado cirúrgico conquistado, é um aspecto pouco abordado pelos profissionais no manejo do aleitamento por não considerarem a questão estética e priorizarem o bem-estar da criança em detrimento da mulher.

Segundo Silva (1997, p.206), o temor pela estética das mamas com a crença que "a amamentação traz modificações anatômicas, tornado-as flácidas, maiores e hipertrofiando os mamilos, repercute de forma negativa nos sentimentos da nutriz podendo ser um elemento decisório para interromper a amamentação".

Assim, parece-nos que o alcance de aspectos, que vão além das técnicas e da biologia feminina para lactar e amamentar, deva ser uma meta de pesquisadores e profissionais, pois concordamos com Masson (2002) quando salienta que aspectos subjetivos do cotidiano da 
mulher freqüentemente não são considerados e fenômenos associados aos baixos índices de aleitamento ainda necessitam ser desvelados.

Considerando o contexto de valorização do corpo feminino, a maior facilidade de acesso às cirurgias estéticas e o elevado nível de satisfação das mulheres com os resultados cirúrgicos, podemos pressupor a progressão de nutrizes com mamoplastia. Portanto, percebe-se a necessidade de compreender a experiência de amamentar de mulheres com mamoplastia e não apenas se limitar a dados quantitativos de volume de leite produzido e tempo de amamentação para nos auxiliar na assistência a essas mulheres. Esse conhecimento irá por fim nos oferecer dados significativos para organizar uma estratégia assistencial que incorpore nas diretrizes de incentivo, apoio e promoção do aleitamento materno, mulheres com experiências diferenciadas de vida e de amamentar, como o caso das mulheres submetidas aos procedimentos de redução ou aumento de mamas.

Em vista disso, o objetivo deste estudo foi o de compreender a experiência de amamentar de mulheres que realizaram mamoplastias redutora ou de aumento. 


\section{BASES TEÓRICAS E METODOLÓGICAS}

A pesquisa que ora apresentamos foi desenvolvida segundo o método qualitativo.

A escolha do método de pesquisa é guiada pelo objeto do estudo, ou seja, pela questão a ser investigada. A pesquisa qualitativa é apropriada ao estudo da experiência humana, pois permite uma compreensão mais abrangente a respeito dos comportamentos humanos em cenários naturalistas (Marcus, Liehr, 2001).

Ao definir a opção metodológica para buscar a compreensão da experiência de amamentar em mulheres com mastoplastia, incluindo aquelas com mamoplastia redutora e as com próteses mamárias, buscamos analisar a adequação da abordagem qualitativa, visto que tal metodologia concentra-se na experiência dos indivíduos e explora as dimensões da singularidade humana. As pessoas são seres complexos que atribuem significado singular as suas experiências dentro de um contexto da sua história pessoal e em interação com 0 ambiente (Marcus, Liehr, 2001).

A metodologia qualitativa permite apreender como os indivíduos pensam e reagem diante às questões abordadas e conhecer os sentimentos, valores, comportamentos e atitudes sob o ponto de vista de quem vivencia o fenômeno. Sua natureza descritiva possibilita a compreensão holística, pois destaca a necessidade de conhecer e interpretar as situações e eventos e os significados das ações e das relações humanas (Meringhi, Praça, 2003).

A pesquisa qualitativa é justificada por ser "capaz de incorporar a questão do significado e da intencionalidade como inerentes aos atos, às relações e às estruturas sociais" (Minayo, 2000, p.10). Tem especial importância na construção do conhecimento sobre Saúde, pois permite "compreender dimensões profundas e significativas que não conseguem ser aprisionadas em variáveis" (Minayo, 2001, p.251) 
A aplicação da metodologia qualitativa, empregada de forma crescente nas pesquisas em Enfermagem, tem permitido a construção do conhecimento, revelando aspectos subjetivos da experiência humana e a compreensão do significado no processo saúde e doença (Merighi, Praça, 2003).

Considerando assim, que o método qualitativo proporciona uma compreensão mais ampliada e profunda a respeito da complexidade dos comportamentos humanos, e tendo em vista 0 objeto do estudo, a opção pela pesquisa qualitativa foi definida por possibilitar a compreensão da experiência de amamentar de mulheres com mastoplastia redutora ou de aumento.

\section{BASE TEÓRICA}

O modelo teórico representativo da experiência de amamentar "Pesando riscos e benefícios", elaborado por Silva (1997), proporciona o suporte teórico deste estudo.

A fim de compreender o processo decisório das mulheres em manter ou interromper 0 aleitamento, Silva (1997) desenvolveu um estudo com 36 mulheres de uma comunidade no município de São Paulo. Sob a perspectiva do Interacionismo Simbólico e adotando a metodologia da Teoria Fundamentada dos Dados revelou a amamentação sob a perspectiva da mulher.

No Interacionismo Simbólico, o comportamento humano tem origem no significado dos eventos para as pessoas, ou seja, o ser humano age aos eventos de acordo com o significado que tem para ele, conforme suas crenças. Os eventos incluem os fatos, idéias, perspectivas e até objetos físicos. O significado resulta ou emerge no processo de interação social entre as pessoas. 
Sob essa ótica, Silva (1997) demonstrou em seu estudo que a mulher age em relação à amamentação de acordo com o significado que essa experiência tem para si. Esse significado pode ser manipulado e modificado ao longo do processo de aleitar.

O modelo "Pesando riscos e benefícios" revela que a mulher vivencia a amamentação como um processo interpretativo contínuo de avaliação e valoração da experiência de aleitar seu filho, ou seja, avalia continuamente a sua capacidade para amamentar e seus sentimentos. É com base no resultado e interpretação dessa avaliação que toma a decisão da continuidade ou da interrupção do aleitamento. Neste processo, pondera o que a amamentação representa em termos de riscos e benefícios para si e para a criança.

Este fenômeno permeia todo processo de amamentação por meio de constante estimativa em termos simbólicos de riscos e benefícios. Os riscos simbolicamente estão associados às perdas para a mãe e o filho ou uma das partes e os benefícios são os ganhos obtidos pela amamentação. Esse fenômeno muitas vezes não é reconhecido pela mulher e por vezes é oculto pela dificuldade dela em compartilhar com seus pares os seus reais sentimentos e desejos em relação à amamentação.

Quando a amamentação é considerada como um risco para a mulher ou quando compreende que os benefícios não têm valor suficiente para superar os riscos identificados, implica em ações e decisões que podem interromper a amamentação. Quando amamentar é considerado pela mulher como benefício para o filho e sem risco para si ou pode superar os possíveis existentes, a amamentação é assegurada em seu curso.

Silva (1997) destaca que a amamentação é centrada na dimensão da mulher, responsável pela tomada de decisão quanto ao curso de aleitar. Este processo não se restringe ao tempo de lactação e a mulher considera situações que muitas vezes antecederam à 
amamentação, ainda na gestação, ou antes. Aspectos econômicos, sociais, familiares, projetos pessoais influenciam na percepção e significado da amamentação para a mulher. A amamentação se integra no contexto da mulher que abarca outros papéis. Um processo dialético de avaliação e estimativa está presente de forma contínua. Neste processo, a mulher define prioridades que influenciam a tomada de decisão do curso da amamentação "Pesando riscos e benefícios", o que nos leva a considerar sua aplicação para compreender a experiência das mulheres que realizaram mamoplastias e que estão em processo de aleitamento materno.

\section{BASE METODOLÓGICA}

O método do Discurso do Sujeito Coletivo (DSC) foi aplicado para organização dos dados deste estudo. O DSC é uma proposta de organização e tabulação de dados de natureza qualitativa, constituindo-se em uma estratégia que utiliza uma forma discursiva e procura tornar claro o que pensa ou como vivencia uma determinada população sobre um determinado tema.

Na construção do DSC, é formulada uma questão aberta para pessoas que representam um grupo que vivenciam o fenômeno a ser estudado. Essa questão possibilita que os indivíduos se expressem espontaneamente por meio de depoimentos.

Os dados empíricos compõem-se de um ou vários discursos na primeira pessoa do singular, em que esse "eu sintático além de sinalizar a presença de um sujeito individual do discurso, expressa uma referência coletiva na medida em que esse eu fala em nome de uma coletividade". O pensamento de uma coletividade é visto como um único discurso que representa todo o conjunto de depoimentos expressos pelos membros de uma dada sociedade e cultura sobre um tema (Lefevre, Lefevre, 2003, p.16). 
Ao utilizar o DSC, os depoimentos de cada participante não se reduzem a categorias unificadoras, já que a proposta do método é reconstruir, com trechos dos relatos individuais, um discurso síntese para expressar um dado pensar ou sentir sobre o fenômeno.

Ao analisar o material coletado, extraem-se as idéias centrais de cada um dos depoimentos. A idéia central revela e descreve de maneira sintética o sentido dos discursos analisados.

As expressões chaves são transcrições de trechos dos discursos que indicam a essência do depoimento e a "ancoragem é uma manifestação lingüística explícita de uma dada teoria que o autor do discurso professa e que na qualidade de afirmação genérica é usada pelo enunciador para enquadrar uma situação específica" (Lefevre, Lefevre, 2003, p.17).

"O DSC é um discurso-síntese que redigido na primeira pessoa do singular e compostos pelas expressões chaves que têm a mesma idéia central e ancoragens." Essa forma de apresentação dos resultados confere naturalidade ao pensamento coletivo (Lefevre, Lefevre, 2003, p.18). 


\section{DESCRIÇAO DA PESQUISA}

\section{0 contexto do estudo}

\section{Local}

O estudo foi realizado em uma maternidade privada localizada no bairro do Morumbi, zona sul da cidade de São Paulo.

A população atendida na instituição caracteriza-se por ser uma clientela de classe socioeconômica e nível educacional elevados, com atendimento particular ou conveniado. A maternidade atende mulheres encaminhadas pelo seu obstetra de escolha, sem vínculo empregatício com a instituição e possui 40 leitos operacionais com taxa de ocupação de $75 \%$. Em 2004, ocorreram em média 240 partos por mês, sendo 77\% cesáreas.

A equipe interdisciplinar da instituição favorece e estimula a prática do aleitamento materno para todas as mulheres que expressam o desejo de amamentar por meio de diversas ações. Destinado aos clientes externos, o curso de preparação para o parto é oferecido para os casais grávidos, focalizando as vantagens da amamentação para a mãe e para o lactente e orienta o manejo do aleitamento materno. Outro encontro denominado "chá dos avós", também realizado pela mesma equipe, é destinado a essa clientela e tem como objetivo a atualização de conceitos. A ênfase que é dada no incentivo ao aleitamento materno é em razão de se considerar que a geração atual de avós vivenciou um período anterior em que a prática comum era oferecer mamadeira com fórmula láctea.

As ações de incentivo à amamentação direcionada aos clientes internos iniciam no momento da admissão da gestante. A enfermeira realiza o exame físico que inclui a avaliação das mamas, investiga o tempo de amamentação anterior, se for o caso, ocorrência de cirurgia mamária e patologias que contra-indiquem a amamentação. Na sala de parto, após avaliação 
do obstetra e do neonatologista, é incentivado o contato precoce da mãe e bebê e a sucção ao seio materno. Na unidade de internação, a enfermeira acompanha a primeira mamada e a equipe de enfermagem presta orientações individualizadas e auxílio durante toda a internação.

As puérperas recebem uma apostila ilustrada, onde constam orientações sobre a amamentação que abrangem os benefícios do leite materno, o processo de lactação, a pega e a sucção correta do recém-nascido na mama, freqüência das mamadas, posições para amamentar e cuidados com as mamas e mamilos. Esse texto também inclui informações sobre o período puerperal, descrevendo as modificações que ocorrem no organismo materno e os cuidados com o recém-nascido, como banho, troca de fraldas e higiene do coto umbilical.

Até 0 momento da alta hospitalar, a rotina institucional favorece que o recém-nascido permaneça a maior parte do tempo ao lado de sua mãe, retornando ao berçário apenas para realização de exames e, por questões de segurança, no momento da passagem de plantão das equipes de enfermagem. Há possibilidade da permanência do recém-nascido no berçário mediante solicitação materna, as quais são mais freqüentes no período noturno. A permanência do bebê ao lado de sua mãe é incentivada com intuito de facilitar a interação mãe-filho, a formação do vínculo e a amamentação (Klaus, Kennel, Klaus, 2000).

Ações educativas, com reciclagem setorial anual sobre amamentação e incentivo para participação em congressos e cursos sobre o tema, são direcionadas à equipe interdisciplinar da maternidade, berçários, centro obstétrico, UTI Neonatal e banco de leite.

\section{Participantes do estudo}

Participaram do estudo 14 mulheres, sendo oito com mamoplastia redutora e seis com prótese mamária, que atenderam aos critérios da inclusão de nutrizes no estudo, ou seja, 
expressaram o desejo em amamentar e apresentavam boas condições clínicas e ambos, mãe e bebê, não tinham qualquer distúrbio impeditivo à amamentação.

Esse número de participantes foi determinado pela percepção da saturação dos dados obtidos, que, segundo Minayo (2000), ocorre quando a amostra é considerada suficiente ao permitir a reincidência de informações e capaz de refletir a totalidade das dimensões do objeto do estudo.

\section{Estratégias e procedimentos para obtenção dos dados}

\section{A estratégia de coleta dos dados}

A entrevista foi o recurso empregado para obtenção dos dados, por ser considerada um instrumento privilegiado de interação e coleta de informações; a fala revela condições estruturais, valores, símbolos, normas e transmite as representações de um grupo e de sua condição histórica, cultural e socioeconômica (Minayo, 2000).

A entrevista é um método de coleta de dados em que o entrevistador questiona o sujeito da pesquisa com o propósito de interrogar e obter informações. Podem ser feitas oralmente ou por telefone. O conteúdo das questões é determinado pelo autor com base na revisão da literatura sobre 0 assunto a ser pesquisado. As questões abertas são empregadas quando 0 pesquisador deseja que o sujeito da pesquisa responda com suas próprias palavras ou quando 0 pesquisador quer conhecer todas as alternativas possíveis para sua questão (Grey, 2001).

As entrevistas, do tipo não estruturada, foram realizadas, iniciando-se por uma questão norteadora: "Conte-me como tem sido a sua experiência de amamentação.". Conforme transcorria a entrevista, outras questões poderiam ser acrescentadas para melhor entendimento 
do fenômeno estudado, seguindo um roteiro de itens de interesse para o objeto do estudo (Anexo 1).

O roteiro de entrevista é um guia elaborado com itens para facilitar e aprofundar a comunicação e apreender a visão e o juízo dos atores sociais previstos nos objetivos da pesquisa. Não há ordem fixa nas questões, as perguntas são formuladas conforme surgem preocupações ou o entrevistado enfatiza um determinado assunto (Minayo, 2000).

\section{Os procedimentos para a coleta dos dados}

A coleta dos dados foi realizada no período de dezembro de 2004 a abril de 2005 . A identificação das participantes era feita durante a visita diária aos berçários, quando a pesquisadora levantava verbalmente, junto à equipe de enfermagem, a internação de mulheres com prótese mamária ou com mamoplastia redutora, que haviam dado à luz naquele dia.

A informação era confirmada com a leitura dos prontuários materno e neonatal, e logo após, a pesquisadora visitava a puérpera em seu quarto com intuito de convidá-la a participar da pesquisa. Nesse contato inicial, a pesquisadora identificava-se e explicava a natureza do estudo, esclarecendo sobre o procedimento de coleta de dados, que consistia em entrevista a ser agendada, dentro de um período aproximado de um mês após o parto e leitura dos prontuários dos quais seriam extraídos os dados, tais como informações sobre o tipo e data da cirurgia, peso do recém-nascido, necessidade de introdução de complemento para o recém-nascido durante 0 período de internação, traumas mamilares, entre outras que pudessem favorecer um maior conhecimento sobre o universo dessas mulheres (Anexo 2). 
A delimitação do prazo, de aproximadamente 30 dias para coleta dos dados, foi definida por se considerar que esse período possibilitava à mulher a vivência da prática da amamentação, em seu contexto de vida e nos daria maiores elementos para compreender a sua experiência.

A entrevista poderia ser concedida na residência ou por telefone, conforme a preferência da participante. A opção de a entrevista ser realizada também por telefone, justifica-se por desconhecermos a aceitação da visita domiciliar das clientes dessa instituição. Caso as clientes recusassem a visita, era necessário dispor de outra forma de coleta de dados de forma a não inviabilizar a pesquisa.

Foi elaborada uma planilha para programação das visitas, contendo nome completo da paciente, número de prontuário, tipo de cirurgia mamária, data do parto, endereço residencial, telefone e data da entrevista (Anexo 3).

Após um mês da data do parto, a pesquisadora telefonava para a participante e programava a entrevista no domicílio. A data, o horário e o local eram escolhidos de acordo com a disponibilidade da entrevistada.

Todas as entrevistas foram realizadas pela pesquisadora, sendo a maioria no domicílio das participantes. Uma entrevista foi realizada por telefone por solicitação materna justificada por razões de segurança. Duas entrevistas foram concedidas por telefone devido à participante residir em outro município, inviabilizando para a entrevistadora a visita domiciliar para coleta de dados.

As entrevistas foram realizadas nos meses de fevereiro a abril de 2005. As entrevistas realizadas no domicílio tiveram duração variável de 45 a 60 minutos, enquanto as realizadas por telefone tiveram tempo médio entre 20 e 30 minutos. 
As entrevistas foram realizadas concomitantemente com a análise dos dados, ou seja, à medida que eram coletados, também se procedia a sua transcrição e a sua análise para se ter clareza da ocorrência da saturação dos dados. Foi finalizado o agendamento de novas entrevistas e encerrada a coleta de dados, no momento em que tais não apresentavam informações diferenciadas das anteriormente coletadas. Nessa ocasião a pesquisadora observou a saturação dos dados e a possibilidade de compreensão do fenômeno.

As entrevistas gravadas foram transcritas para iniciar a tabulação dos dados. O fato da própria pesquisadora transcrever as gravações favoreceu a análise dos depoimentos, tendo a oportunidade de valorizar as mudanças de entonação de voz, as pausas dos relatos e trechos onde transparecia a emoção da participante.

$\mathrm{Na}$ análise de cada entrevista transcrita, foram identificas e assinaladas as expressões chaves e as idéias centrais dos discursos, procedendo à construção dos DSCs.

\section{Aspectos éticos}

Na primeira oportunidade de contato com as mulheres, foi explicado o objetivo do estudo e sua finalidade, cujos resultados visam a nortear a assistência no aleitamento materno da equipe interdisciplinar. A seguir era feito o convite para que elas participassem do estudo.

A pesquisadora esclareceu todas as dúvidas que as mulheres apresentaram sobre a pesquisa, além de explicar-lhes a possibilidade de interromper a participação a qualquer momento sem qualquer prejuízo à participante e ao seu filho, sobre a ausência de risco para a participante e seu filho, a garantia de anonimato e sigilo dos dados obtidos para elaboração desta pesquisa, que seria por meio de entrevista gravada em K-7, bem como, que não haveria compensação financeira para participação. Na ocasião, eram esclarecidas as dúvidas quanto ao 
Termo de consentimento livre e esclarecido, do qual the eram entregues duas vias para assinatura, sendo que uma delas era fornecida à participante (Anexo 4).

O termo de consentimento livre e esclarecido, apresentado às participantes, contém 0 título provisório da pesquisa e seu texto foi elaborado em linguagem adequada à clientela do estudo. Constam no termo as informações da autora como categoria profissional, cargo e local de trabalho, seu endereço residencial e telefones para contato.

O estudo foi realizado de acordo com a Resolução 196/1996 sobre Pesquisa envolvendo Seres Humanos do Conselho Nacional de Saúde e aprovado pela Comissão de Ética da Instituição em 14/12/2004 com número Ref CEP/Einstein n. ${ }^{\circ}$ 04/209. 


\section{OS DISCURSOS REPRESENTATIVOS DAS EXPERIÊNCIAS DAS MULHERES}

A fim de favorecer a compreensão dos Discursos do Sujeito Coletivo apresento algumas informações a respeito do perfil das mulheres participantes do estudo (Anexo 5).

O grupo de mulheres apresenta idade entre 26 e 42 anos, sendo a média de 34 anos. Todas as mulheres com nível de escolaridade superior e exercendo atividade profissional remunerada. Apenas uma estava sem vínculo empregatício por opção pessoal de interromper sua atividade profissional, justificando seu desejo de dedicar-se ao acompanhamento da educação e crescimento dos filhos.

No grupo havia oito mulheres com mamoplastia redutora e seis com prótese mamária. 0 tempo da cirurgia variou entre dois a 17 anos, em média dez anos.

Cerca de cinco mulheres eram primíparas, sete secundíparas, duas tercíparas. Entre as nove mulheres já com filhos, sete tinham um e duas cerca de dois filhos. Destas nove, sete amamentaram o filho anterior. O tempo de amamentação variou de três a 12 meses, sendo em média seis meses.

Quase a totalidade das mulheres teve parto cesárea e duas, parto normal. Apenas seis mulheres experimentaram a amamentação precoce em sala de parto, ao nascimento do filho.

A maioria das mulheres apresentava mamilos protrusos e três semiprotrusos, os quais estavam no grupo de mulheres com mamoplastia redutora. Foi considerado protruso o mamilo que após estímulo protraía facilmente e apresentava-se bem delimitado, formando ângulo de $90^{\circ}$ na junção mamilo areolar e semiprotruso aquele que protraía com dificuldade, apresentava-se pouco saliente e não havia delimitação precisa entre o mamilo e a aréola (Vinha,1994). 
Ao iniciar a amamentação, durante o período de internação hospitalar, dez mulheres apresentaram traumas mamilares. Foram descritos em prontuário três casos de hiperemias e seis de escoriações, sendo que em quatro destes há outras lesões associadas, como fissuras, vesículas equimoses.

Vinha (1994) classifica os traumas mamilares e descreve a fissura como uma ulceração linear, tipo fenda, acometendo a derme e epiderme, localizada na junção mamilo areolar ou na superfície do mamilo. Define a escoriação quando a lesão do mamilo assemelha-se a esfoliação e atinge a derme.

Na gestação atual, as mulheres tiveram recém-nascidos a termo sendo 11 adequados à idade gestacional, dois grandes para a idade gestacional e um pequeno para a idade gestacional.

Durante 0 período de internação hospitalar, apenas dois recém-nascidos receberam fórmula láctea $30 \mathrm{ml}$ após amamentação, sendo um no terceiro e outro no quarto dia de vida, respectivamente. As mães desses recém-nascidos tinham mamoplastia redutora.

Na ocasião da entrevista, cerca de aproximadamente um mês após o nascimento, cinco recém-nascidos estavam em aleitamento materno exclusivo, sete em aleitamento materno, ou seja, recebiam leite materno e outros alimentos líquidos e dois alimentados apenas com fórmula láctea. No grupo de mulheres com prótese mamária, os lactentes estavam em aleitamento exclusivo e metade em aleitamento materno. No grupo de mulheres com mamoplastia redutora, dois lactentes foram desmamados, dois estavam em aleitamento exclusivo e os demais em aleitamento materno.

Para caracterizar a situação de amamentação/alimentação da criança utilizamos as categorias propostas pela OPAS/OMS,1991, em que foi acrescentada a categoria desmame (D): 
- aleitamento materno exclusivo (AE): a criança recebe apenas leite materno, diretamente da mama ou extraído e nenhum outro líquido ou sólido, com exceção de medicamentos ou suplementos vitamínicos;

- aleitamento materno predominante (AP): a criança recebe leite materno diretamente da mama ou extraído, e água ou bebidas à base de água (chás, sucos) e nenhum outro alimento líquido ou sólido;

- aleitamento materno (AM): a criança recebe leite materno, diretamente da mama ou extraído, independente de estar recebendo também qualquer outro alimento líquido ou sólido, inclusive outros leites;

- desmamado (D): quando a criança já não recebe mais o leite materno, mas outros tipos de leite ou alimentos líquidos ou sólidos.

Com base na análise dos depoimentos das mulheres com mamoplastias de aumento ou redutora foram construídos 16 DSCs, distribuídos em quatro temas, sendo que um dos temas constituiu-se no próprio discurso. Os DSCs revelam o movimento das mulheres em buscar a mamoplastia para obter maior satisfação com a imagem corporal e as ansiedades decorrentes da opção cirúrgica que afloram na gestação ou no pós-parto ao se depararem com a prática da amamentação e nos permite fazer uma aproximação da vivência dessas mulheres que apresentamos a seguir. 
OS TEMAS E OS DSC CORRESPONDENTES

TEMA 1. A OPÇÃO PELA CIRURGIA PLÁSTICA E O PROJETO DE AMAMENTAÇÃO

Motivação para mamoplastia redutora

Motivação para a mamoplastia de aumento

Satisfação com o resultado da cirurgia

Parcialmente satisfeita com o resultado da cirurgia

O projeto de amamentar

Não se preocupou com a amamentação

TEMA 2. VIVENCIANDO A PRÁTICA DA AMAMENTAÇÀO

A produção de volume insuficiente de leite

Buscando soluções para o volume insuficiente de leite

A produção de volume suficiente de leite

Enfrentando os desconfortos da amamentação

TEMA 3. REFLEXÃO SOBRE A INTERFACE DA CIRURGIA COM O PROCESSO DA

AMAMENTAÇÃO

Julgando que a cirurgia não interferiu na amamentação

Tendo prazer em amamentar

Julgando que a cirurgia prejudicou a amamentação

A culpa e 0 arrependimento

Se precisar, eu faço outra

TEMA 4. CONCILIAR O PAPEL DE MÃE, NUTRIZ E MULHER - NÃO É FÁCIL 


\section{TEMA 1. A OPÇÃO PELA CIRURGIA PLÁSTICA E O PROJETO DE AMAMENTAÇÃO}

Como já foi comentado, o tempo decorrido entre a realização da cirurgia e o nascimento das crianças, foi em média de dez anos, sendo que o menor tempo transcorrido, para três das mulheres, foi de dois anos. Podemos inferir, portanto, que apesar de algumas dessas mulheres, por ocasião da cirurgia, poderem apresentar o desejo de ter filhos no futuro, a decisão pela mamoplastia assumia uma importância significativa em suas vidas e por assim dizer, exclusiva, não havendo a previsão de uma gravidez imediata ou planejamento da mesma que pudesse suscitar uma reflexão mais aprofundada sobre as implicações do procedimento cirúrgico sobre a lactação.

Dessa forma, a insatisfação com o tamanho e aspecto de suas mamas, acrescido de desconforto físico ou emocional, foi a motivação principal para a busca da mamoplastia. As mulheres referem que suas mamas eram inadequadas para seu corpo, considerando-as volumosas ou muito reduzidas, e que recorreram à cirurgia estética para conquistar não apenas uma mama apropriada ao tipo físico, mas também para obter maior satisfação pessoal. Assim, apesar de serem submetidas a técnicas e resultados diferentes, o objetivo dessas mulheres pode ser considerado o mesmo, como é possível compreender por meio dos DSCs de quem se submeteu à redução ou ao aumento das mamas.

\section{Motivação para mamoplastia redutora}

Discurso do Sujeito Coletivo T1/DSC1:

"Eu tinha o seio muito grande. O tamanho do meu seio era uma coisa que incomodava bastante, era muito grande, muito desproporcional, 
era muito pesado. O sutiã afundava na pele, no ombro, marcava as minhas costas e estava começando a ficar curva. Era uma coisa que inclusive me bloqueava em relacionamentos, com amigos, com tudo. Atrapalhava muito. Eu estava superinsatisfeita e fui visitar uns médicos. Então não foi só estética, foi uma necessidade médica mesmo. Não foi só estética."

O conteúdo do DSC das mulheres com mamoplastia redutora, devido à hipermastia, ressalta a amplitude e intensidade de desconfortos físicos e as implicações emocionais no período que precedeu a opção cirúrgica. São expressas também as dificuldades de ajuste social e de estabelecer relacionamentos.

Diversos trabalhos científicos descrevem as alterações físicas das mulheres com macromastia. Cefaléia, dores na região cervical, lombar ou dorsal e alterações posturais são os sintomas mais freqüentemente citados. Em agravo aos distúrbios clínicos, as mulheres referem sofrimento emocional e vergonha de suas mamas. Essas mulheres se distanciam de atividades sociais e esportivas por sentirem-se embaraçadas com o tamanho das mamas (Smith, Kent, 2002).

\section{Motivação para a mamoplastia de aumento}

Discurso do Sujeito Coletivo T2/DSC2:

"Eu nunca tive peito. Eu não tinha quase nada, sabe, era uma coisa que me incomodava muito. Então eu coloquei a prótese de silicone só para também ter alguma coisa. Foi superfácil com anestesia local e pelo que eu 
lembro da época não senti nada. Não fiz com o intuito de ter um peito maravilhoso, mas de corrigir, só foi mesmo um suporte, não foi um luxo."

Assim, fica evidente no DSC das mulheres com hipomastia, as quais optaram pela inserção cirúrgica de prótese mamária, que, embora não relatem desconfortos físicos, expressam acanhamento com o pequeno volume das mamas e também vivenciam dificuldades sociais. Essa constatação vem ao encontro dos achados do estudo qualitativo conduzido por Logothetis (1995), no qual mais da metade das entrevistadas, que optaram pela mamoplastia de aumento, referiram que se sentiam desconsideradas e inferiores como mulheres devido ao pequeno tamanho de suas mamas.

O estudo de Ribeiro et al. (1992), com objetivo de pesquisar motivações de pacientes para mastoplastia, encontrou que as mulheres sentiam-se inadequadas com a imagem corporal, sofriam gracejos que as irritavam e as entristeciam, agravando ainda mais a sua baixa autoestima. Sentimentos penosos de humilhação perante outros são relatados decorrentes de comentários vexatórios de pessoas próximas e até de estranhos (Logothetis, 1995).

Nos discursos dessas mulheres, embora o procedimento cirúrgico tenha finalidades distintas de redução e aumento das mamas, em ambas as situações, observa-se a busca em obter maior satisfação com a forma do corpo devido ao desagrado com a própria aparência.

Essa asserção vem de acordo aos resultados do estudo de Cash, Duel, Perkins (2002) que relatam que as mulheres recorrem à cirurgia porque desejam obter maior satisfação com a própria imagem, especialmente quanto ao tamanho e formato das mamas e obter um corpo de dimensões proporcionais. 
Segundo Young, Nemecek, Nemecek (1993), as mulheres que recorrem a mamoplastia, têm perspectivas realísticas e não buscam um padrão inatingível de beleza, mas procuram diminuir o descontentamento pessoal, obtendo uma mama que percebem como adequada ao seu tipo físico.

As mulheres freqüentemente reportam insatisfação ao comparar a imagem corporal percebida com aquela idealizada. Distúrbios com a auto-imagem são associados com alterações psicológicas, baixa auto-estima, excessiva preocupação com a aparência e fobia social (Smith, Kent, 2002).

Neste estudo, observa-se que, embora as mulheres reconheçam as dificuldades sociais e emocionais que vivenciam decorrentes do volume excessivo ou reduzido das mamas, elas precisam enfatizar e justificar a cirurgia plástica não como procedimento estético, mas como uma "necessidade", em virtude dos sintomas físicos e emocionais apresentados.

Ainda que a cirurgia plástica seja uma especialidade consolidada, com relativa facilidade de acesso por parte das mulheres, em especial da classe social mais favorecida, as falas das participantes deste estudo parecem revelar o receio das mulheres em enfrentar o preconceito percebido no grupo social. Garbers, Terry, Toniolo (1998), ao avaliar a acurácia das informações prestadas pelas mulheres quanto à presença de prótese mamária em comparação com registros de prontuário, encontraram validade nas informações em $89,3 \%$ dos casos. Uma percentagem de mulheres omite, intencionalmente ou não, a realização da cirurgia. Esse fato também é observado na nossa prática assistencial.

Parece que um estigma social paira sobre as mulheres que recorrem às cirurgias plásticas. Surge a questão, se o corpo moldado por cirurgia, cuja beleza foi construída, tem um valor menor que a beleza natural. Essa possibilidade justifica a dificuldade de algumas mulheres 
em expor que se submeteram à cirurgia estética, como se a vaidade, embora seja valorizada pela sociedade contemporânea, sofre recriminação.

O resultado da cirurgia, percebido por essas mulheres, é qualificado mediante a sua expectativa, quanto ao formato e tamanho das mamas e ao processo de cicatrização, que passa a constituir um elemento estético importante. Foram encontrados dois discursos que expressam 0 grau de satisfação com o procedimento cirúrgico.

\section{Satisfação com o resultado da cirurgia}

Discurso do Sujeito Coletivo T1/DSC3:

"Eu fiquei superfeliz, satisfeita. Você nem imagina o quanto! Você nem imagina! Se eu soubesse que era tão fácil, eu tinha feito há mais tempo, porque eu não tive absolutamente nada. Tanto que eu não tinha nenhuma dor. Ficou bem feitinha, ficou bem no lugarzinho certo. Eu não tenho cicatriz nenhuma, não tenho aqueles quelóides. Faria de novo sem problema nenhum. Claro se fosse hoje eu iria querer um peitão, é estética mesmo."

As mulheres expressam de forma entusiástica a satisfação com o resultado da cirurgia estética quando a expectativa é preenchida, referindo-se tanto quanto ao procedimento que deveria ter feito há mais tempo como na possibilidade de submeter-se novamente à plástica.

Trabalhos científicos confirmam a elevada satisfação das mulheres com o resultado cirúrgico das mastoplastias. Na pesquisa conduzida, Young, Nemecek, Nemecek (1994) constataram que cerca de $95 \%$ das mulheres submetidas à mamoplastia de aumento 
responderam que a cirurgia atendeu as expectativas e $81 \%$ fariam a cirurgia novamente. Resultados semelhantes foram encontrados por Cash, Duel, Perkins (2002). Cerca de 90\% das pacientes submetidas à inserção de prótese mamária estavam satisfeitas com o resultado após seis, 12 e 24 meses da cirurgia. Em mulheres com mamoplastia redutora, o índice de satisfação encontrado por Aboudib Junior et al. (1991) foi de 92\%.

Ferreira (2000) elaborou um escore de avaliação do resultado cirúrgico aplicado após seis meses da mamoplastia redutora, com pontuação de zero a dez, com os itens de simetria, formato, volume, aréola e cicatriz. A pontuação de zero a quatro indicava a insatisfação devido às deformações na mama e escores acima de sete, bons resultados cirúrgicos. Aplicado em 91 mulheres, 70 deram escore entre sete e nove e não houve nenhum escore abaixo de quatro. Cerca de 68 pacientes expressaram uma mudança positiva no humor. O autor salienta que, na avaliação do resultado cirúrgico pela paciente, critérios subjetivos relacionados a aspectos psicológicos estão associados às questões objetivas, como o alívio de sintomas físicos e melhoria da aparência das mamas.

No grupo de mulheres deste estudo, sentimentos de felicidade são mencionados associando-os ao resultado satisfatório da cirurgia.

Blomqvist, Brandberg (2004), ao compararem dados pré e pós três anos de cirurgia, observaram que as mulheres reportaram mudanças positivas em suas vidas por se sentirem menos incomodadas em ocasiões sociais e em situações íntimas. Concluíram que mamoplastia redutora é um tratamento eficiente dos distúrbios psicológicos das pacientes com macromastia, além de reduzir desconfortos e promover o alívio da dor.

Embora as metas a serem atingidas pelos dois tipos de cirurgia sejam diferentes, e essas mulheres serem submetidas a procedimentos variados, a cirurgia e a recuperação pós-operatória 
parecem ser percebidas com uma simplicidade maior do que a imaginada. No DSC acima, as ausências de dor e de complicações após a cirurgia reforçam essa impressão. A percepção de ausência de complicações com a cicatrização nas mamas agrega valor ao resultado cirúrgico para essas mulheres.

A preocupação em manter a imagem corporal conquistada e até mesmo aprimorá-la, aparece de forma velada no relato da possibilidade de repetir a cirurgia.

\section{Parcialmente satisfeita com o resultado da cirurgia}

Discurso do Sujeito Coletivo T1/DSC4 :

"Satisfeita 100\% não, porque não ficou tão bonito, porque eu tive que fazer duas cirurgias e acabou realmente não ficando maravilhoso, mas ficou bom. Eu fiquei com quelóide. A mama não ficou super em pezinho assim, ficou bem, não ficou caída, mas eu acho que ela poderia ter ficado mais levantada. Mas de resultado assim de consistência, para palpar, eu achei que ficou ótimo, ficou bem melhor do que tava. Então, esteticamente ficou péssimo [ externamente]. É, ficou uma coisa muito feia."

Por outro lado, pode-se observar, pelos dados acima apresentados, que o procedimento cirúrgico nem sempre é satisfatório do ponto de vista das mulheres.

Assim, como outros procedimentos cirúrgicos, a mamoplastia não é isenta de riscos e complicações. Young, Nemecek, Nemecek (1993) reportaram que 21\% das pacientes com inserção de prótese mamária sofrem complicações pós-cirúrgicas e entre as mais freqüentes 
encontramos a formação de cicatrizes antiestéticas, quelóides e assimetrias nas mamas (Smith, Kent, 2002).

A cicatriz cirúrgica e a não correção da ptose foram os principais indicadores de insatisfação para as mulheres do estudo que se sentiram apenas parcialmente satisfeitas. 0 tamanho e a forma da cicatriz tiveram um peso significativo na avaliação negativa do resultado cirúrgico para esse grupo de mulheres.

O mesmo resultado foi encontrado no trabalho de Aboudib Junior et al. (1991), no qual reportaram que as queixas de mulheres com o resultado da cirurgia estão, em sua maioria, associadas à presença de cicatrizes antiestéticas. Ferreira (2000) constatou que a queixa mais significante das pacientes com mamoplastia redutora é a cicatriz e metade das pacientes qualificou-a como ruim embora $84 \%$ tenham referido que repetiriam a cirurgia.

Ribeiro et al. (1992) observaram que, ao abordar o tema cicatriz na entrevista précirúrgica, as candidatas à mastoplastia afastavam ou negavam esse assunto e referiam que detinham suficiente informação. Os autores consideram que essa dificuldade está relacionada ao fato que o momento pré-cirúrgico é de euforia para as pacientes, que tendem a afastar possíveis resultados que não as satisfaçam.

É interessante ressaltar que mesmo nos casos que o procedimento não conseguiu atingir a expectativa das mulheres, elas, estabelecendo uma comparação entre a mama pré e póscirúrgica, estão mais satisfeitas com a mama atual.

Por ocasião da opção e decisão em fazer a mamoplastia, a preocupação com as implicações da cirurgia, sobre a lactação e amamentação, pode estar presente ou não para as mulheres, conforme observa-se nos próximos DSCs. 


\section{O projeto de amamentar}

Discurso do Sujeito Coletivo T1/DSC5:

"A gente tem aquele sonho de amamentar, de ter tudo lindo e maravilhoso. Foi a primeira coisa que eu perguntei para o [cirurgião] plástico 'se eu poderia amamentar depois'. Então eu pedi ao médico para fazer um método que não fosse me prejudicar na amamentação no futuro.

Quando eu engravidei, eu não sabia se eu ia poder ou não amamentar. Meu problema era 'será que eu vou poder amamentar meu filho com o meu leite?' Eu fiquei com medo de não ter leite, eu morria de medo de não ter leite. Essa era minha grande preocupação, se eu ia ou não ia ter leite. Na verdade eu tinha medo de não conseguir amamentar.

Daí eu conversei com todo mundo, parece que na hora da amamentação a redutora é mais traumática do que a própria prótese. Os casos de redutora que eu conheço todas tiveram problema, mas prótese, não. Eu conheço tanta gente que amamenta com prótese. Mas eu tenho minhas dúvidas. Eu tenho uma grande amiga que fez redutora e ela amamenta exclusivo e uma que colocou silicone e amamentou sem problema. Minha irmã nunca fez cirurgia e o filho dela urrava, passou fome. Ela amamentou um mês porque ela não tinha leite, tinha muito pouco leite, mas ela era uma pessoa normal, ela tinha que ter leite. Então, eu não sei.

Eu gostaria que eu fosse mais bem preparada para lidar com isso, soubesse mais o que acontece. Sei que cada caso é um caso, mas eu tentei achar estatísticas, achar coisas que eu poderia estar fazendo para eu ter mais leite ou para, sei lá, desentupir os ductos, qualquer coisa assim. E existe muita falta de informação e a 
resposta que eu tive em várias ocasiões foi 'espera para ver se você vai ter leite e aí a agente vê o que é que faz'."

Os benefícios do aleitamento e superioridade do leite materno, em comparação com as fórmulas lácteas para o desenvolvimento do lactente, foram exaustivamente documentados em trabalhos científicos e propagados no meio acadêmico e público por meio de campanhas educativas de incentivo à amamentação (Almeida, 1999). As campanhas nacionais em prol do aleitamento materno aproximam a questão do aleitamento ao universo feminino, sendo uma norma social que garante aprovação da mulher em sua função materna e evita a desaprovação social. Ainda, a amamentação é concebida como parte da natureza feminina e o desejo idealizado de amamentar para dar o melhor ao filho é respaldado no discurso oficial vigente, fazendo muitas vezes, com que a amamentação seja uma meta a ser alcançada para conferir à mulher uma qualificação de seu papel materno e suprir uma expectativa pessoal dessa função. (Nakano, 1996; Nakano, 2003).

Fica evidente no DSC acima que as informações sobre as repercussões futuras da cirurgia são escassas, podendo ser uma fonte de ansiedade para a mulher que deseja ter filhos e amamentar. A observação que informações pré-operatórias não atingiram a abrangência esperada pelas mulheres está de acordo com o estudo conduzido por Ribeiro et al. (1992). Cerca de $66 \%$ das pacientes consideraram que as orientações pré-operatórias obtidas na consulta médica não foram satisfatórias, mas não buscaram maiores informações por sentirem-se "culpadas por ocupar o médico que estava cuidando de outro paciente portador de uma doença real". Os autores concluíram que a cirurgia estética é pouco valorizada como procedimento pelos 
cirurgiões e pacientes implicando em orientações pré-cirúrgicas inadequadas (Ribeiro et al.,1992, p.291).

Observamos que nas participantes deste estudo é possível identificar a expectativa em relação à amamentação, mesmo antes da possibilidade da gravidez, indicando o desejo de experienciar a amamentação, demonstrando uma visão romântica da maternidade, sendo representada pelo sonho de amamentar.

Dessa forma, para algumas mulheres, a preocupação sobre sua futura condição de nutriz já se manifesta antes da cirurgia, o que a faz questionar sobre os possíveis prejuízos desta, em especial à capacidade funcional das mamas, buscando uma garantia, junto ao profissional de preservação da função lactacional.

Essa preocupação se intensifica com a gravidez, quando a mulher percebe que deverá ocorrer o enfrentamento da situação que já a preocupava anteriormente, que se traduz pelo medo de não conseguir amamentar o filho, em especial pela suspeita de que suas mamas não serão capazes de produzir leite suficiente para a criança. Assim, a alimentação do bebê torna-se uma necessidade concreta e a amamentação volta a ser apreciada e analisada quanto à viabilidade de sua implementação. A ansiedade em relação ao aleitamento permeia o transcorrer da gestação.

Essa dúvida ou temor conduz a mulher à busca de novos esclarecimentos, e ainda, à observação de performance lactacional de outras nutrizes, tanto as que se submeteram a cirurgias como outras que não a fizeram, constatando que, apesar de apresentarem condições diferentes, elas também não apresentam uma uniformidade quanto ao exercício da prática da amamentação. Afinal, o recurso de observar a experiência de outras mulheres não traz elementos para esclarecer como será seu futuro. Nessa perspectiva, reiterada pela falta de 
informação ou esclarecimentos, a coloca na condição de aguardar a prática concreta da amamentação para averiguar como suas mamas se comportarão quanto à produção e ejeção do leite.

Silva (1997) esclarece que a atitude da mulher em relação à amamentação é determinada por concepções formadas antes mesmo da sua prática de amamentar. Durante a gestação a mulher "estabelece metas para o futuro" e "planeja a alimentação do filho". A possibilidade de vivenciar 0 aleitamento é avaliada quanto às vantagens e desvantagens, considerando o bebê e os seus valores pessoais. A percepção da gestante em relação ao valor do leite materno, da experiência de aleitar de outras mulheres e dos sentimentos relacionados à amamentação, determina sua intenção futura de amamentar. O processo de valorização do aleitamento pode influir na atitude da mulher e na sua disposição em amamentar. A intenção de amamentar gera expectativas quanto a sua capacidade de produzir leite em quantidade adequada para atender às necessidades da criança.

Assim, no caso das mulheres deste estudo, a expectativa quanto ao amamentar está acrescida de um dado concreto de possibilidades e dúvidas quanto a lesões, ou não em suas mamas, provocadas pela cirurgia para o que ela não encontra outra alternativa que não seja a de esperar para ver 0 que acontece.

\section{Não se preocupou com a amamentação}

Discurso do Sujeito Coletivo T1/DSC6:

"Acho que é uma coisa que quando a gente opera relativamente jovem com dezesseis, dezoito anos, a gente não pensa. Na época você não pensa, mas depois, quando começa a pensar em ter filhos, fala: e agora o que é que eu fiz ?" 
Para algumas mulheres, a amamentação como uma possibilidade futura não foi tema de interesse ou de preocupação quando realizaram a cirurgia. O fato de não mencionarem uma preocupação com os resultados da cirurgia sobre a funcionalidade e estrutura das mamas, que viesse a trazer prejuízo para uma amamentação futura, não implica em interpretar que essas mulheres não tinham esse projeto, apenas isso não era algo que previam acontecer a curto prazo. Elas referem que a estética era a principal questão a ser tratada naquele momento e a amamentação não era algo a ser ponderado para a sua decisão, justificando-se com a imaturidade própria da juventude.

Em estudo realizado com mulheres no período pré-cirúrgico, as preocupações mais significativas das que estavam decididas a recorrer a mamoplastia de aumento foram quanto à ruptura do implante (58\%), alterações na sensibilidade mamilo-areolar (52\%), interferências no exame de mamografia para detecção de câncer (47\%), cicatriz cirúrgica (44\%) e dor (43\%) (Cash, Duel, Perkins, 2002). O aleitamento não foi reportado como uma preocupação no período decisório da mamoplastia. A preocupação com o aleitamento foi evidenciada apenas no momento em que as mulheres decidiram ter filhos ou durante a gestação quando depararam com a questão da alimentação do bebê e o desejo de amamentar. Nessas ocasiões, o receio da impossibilidade de lactação é manifestado gerando medo de insucesso do aleitamento. 


\section{TEMA 2. VIVENCIANDO A PRÁTICA DA AMAMENTAÇÃO}

Segundo o modelo "Pesando riscos e benefícios", as mulheres vivenciam a amamentação em um processo constante e cotidiano de avaliação da sua capacidade de produzir leite, dos efeitos da amamentação sobre o bem-estar do filho e de seu próprio. Neste estudo, as participantes também demonstraram essa preocupação, porque a dúvida em a relação à condição funcional de suas mamas já está presente, conforme apresentado anteriormente, desde a opção pela cirurgia ou durante a gestação. Ao passo da avaliação da produção do leite, a mulher também percebe como a amamentação pode interferir em seu bem-estar e em suas atividades, o que pode qualificar a experiência de amamentar e constituir em determinantes para a condução da amamentação.

Assim, no que concerne a sua capacidade de produzir leite, o volume percebido pode ser considerado suficiente ou insuficiente, determinando para muitas delas uma experiência concreta da prática da amamentação que traz a certeza do sucesso ou da frustração da expectativa de poder amamentar.

\section{A Produção de volume insuficiente de leite}

Discurso do Sujeito Coletivo T2/DSC1:

"Uns dois meses antes de eu dar à luz, eu comecei a ter colostro. Eu apertava e saía. Então, a gente achou que eu ia ser uma vaca leiteira. Estava tudo indo cor-de-rosa, então, eu não fiquei preocupada, eu achei que fosse dar tudo certo. Na primeira mamada ele já pegou direitinho. Ele abocanhava direitinho, ele sugava bastante. Viram que eu 
tinha colostro e eu fiquei hiperfeliz. No começo parecia mesmo que eu ia ter bastante leite.

Quando nós voltamos da maternidade, no final de semana foi bem difícil, porque ele chorava o dia inteiro. Ele acordava e em meia hora ele estava chorando de fome. Ele sugava, mas chorava de fome. Chorava o dia inteiro querendo mamar, se esgoelava de fome, coitado.

Então eu percebi que a quantidade de leite não foi muita, não era suficiente para amamentar o nenê, para ele ficar satisfeito. Cada vez mais ele estava ficando impaciente com o meu peito, porque ele sentia fome e o peito não dava vazão logo no começo. Eu te falo, ele estava mamando nada no meu peito. Estava mamando quase nada, mas alguma coisa ia. Tinha que complementar. Eu dava o complemento só para garantir que ele não estava passando fome e ele fica feliz da vida.

Estávamos acompanhando o peso, vendo se ganhava aquelas trinta gramas pelo menos, quarenta gramas que seria o ideal. E estava correspondendo no começo, mas o ganho de peso não era suficiente. Ele perdeu peso, tinha emagrecido mais ainda. Ele também teve icterícia e quando ele também estava com icterícia eu não queria deixar ele mais cansado ainda de ficar sugando.

A gente começou com um pouquinho de complemento, mas ele não estava se satisfazendo. Ele sentia muita fome e aí depois a gente foi aumentando. Ele já vinha tão agitado, com fome e aí sabe, você começa a não dar. Agora se você me perguntar se eu tenho leite, eu tenho, mas não é o suficiente para ele, não mesmo. A necessidade dele é maior que a minha produção. E aí eu tive que parar de amamentar e continuar só na mamadeira. Então, foi tudo por água abaixo." 
Pelos dados apresentados, observa-se que a presença do colostro durante a gestação, de certa forma, traz um alívio e tranqüilidade para a mulher, que acredita ser este um sinal de que a mama tem sua capacidade funcional preservada. Na gestação, é comum as mulheres valorizarem a expressão de colostro de suas mamas como um sinal positivo e associado com provável abundante produção de leite e sucesso na amamentação futura, em especial quando a mulher tem essa intenção que, segundo Silva (1997), pode estar sustentada pela concepção sobre os atributos e benefícios do leite materno e sua percepção da prática da amamentação.

Almeida (1999) relata que parece existir uma relação direta entre a vontade de amamentar e a produção de leite em algumas gestantes. O autor explica que a decodificação neuroquímica da percepção positiva da mulher quanto à amamentação, dificulta a síntese de peptídeos supressores da lactação e favorece o início da produção do leite, sendo este um fator de grande importância para a instalação do aleitamento materno.

No entanto, ao iniciar a amamentação, as mulheres compreendem esse processo como dependente da mulher e do bebê, o que as leva também a avaliar o desempenho da criança quanto à capacidade de abocanhar e sugar com vigor. Uma vez averiguado que o lactente realiza a sucção adequada, a mulher passa a perceber em si os sinais que determinam a capacidade de produção e manutenção láctea.

Segundo Silva (1997), apesar da decisão prévia, é na prática de amamentar que emergem novos fatores maternos e do bebê, que determinam sua continuidade ou não. A mulher "avalia sua capacidade para amamentar" quanto a sua condição biológica da produção do leite, da condição física para amamentar e a repercussão no bem-estar de seu filho e de si. Esse processo contínuo de avaliação durante a experiência de amamentação a faz reformular o plano inicial estabelecido e isso pode ser observado nas falas das mulheres deste estudo. 
A sucção do bebê na mama, seguida de choro, foi para as mulheres, sinal indicativo de fome e de produção insatisfatória de leite para atender à necessidade do filho. Estas reconhecem a produção de leite, mas julgam o volume como insuficiente.

Em trabalho realizado por Ramos, Almeida (2003), o choro do bebê, considerado um sinal de fome e de problemas com a quantidade e constituição do leite, foi um fator de desmame.

As participantes do nosso estudo, ao "cuidar da alimentação do filho", também tomaram como referência as manifestações comportamentais do lactente que apareceram como um fator preponderante na avaliação do processo de amamentar. A nutriz observa o choro, sono, duração e intervalo das mamadas, assim como o crescimento e desenvolvimento do seu filho. Nesta avaliação considera se ele está bem alimentado ou não e re-examina a continuidade da amamentação. Se interpretar que seu filho não está se alimentando adequadamente, executa ações para solucionar o problema identificado. Manifestações de fome, irritação e doenças elevam a insegurança materna, o que reitera os dados apresentados por Silva (1997).

Masson (2002) observa que as mães avaliam de forma contínua o comportamento do filho quanto ao choro, períodos de sono e vigília e freqüência das mamadas e qualificam a amamentação como insuficiente na incapacidade de saciar a necessidade de sucção do bebê, buscando alternativa como a oferta de chupeta ou complemento.

A oferta de complemento é percebida como um auxílio ao bebê, minimizando o desgaste em sugar uma mama "vazia" e "que não dá vazão". Segundo Silva (1997), na compreensão da mulher não compensa oferecer parte do leite produzido se há fórmulas lácteas disponíveis e que atendem à necessidade da criança. 
Outros indicadores foram empregados pelas mulheres para retratar a produção insuficiente de leite, tais como o acompanhamento da curva de peso e a necessidade de volumes crescentes de complemento de fórmula láctea para satisfazer o recém-nascido.

Ao avaliar a saúde de seu filho, o crescimento da criança é para a nutriz um indicador de alimentação adequada. A perda ou o ganho de peso insuficiente aponta que a amamentação não está apropriada, o leite materno não está adequado e suficiente às necessidades da criança. Ao proceder a avaliação do leite que produz, a mulher não só quantifica o volume, mas qualifica 0 leite que está produzindo como fraco ou forte e que, segundo o modelo teórico aqui utilizado, é a combinação dessas avaliações que determina a capacidade materna de amamentar.

No entanto, chama a atenção que as mulheres deste estudo só apresentaram uma avaliação quanto ao volume de leite, para o que a sua capacidade de amamentar esteve diretamente relacionada à produção de quantidade suficiente de leite, não havendo referência quanto à qualidade do leite.

Pode-se inferir que essas mulheres, por terem um nível alto de escolaridade e receberem orientações sistemáticas sobre amamentação, além do acesso a várias fontes de informação, não apresentaram dúvidas quanto à qualidade do leite materno, mas centram suas preocupações no volume do leite, que poderia estar comprometido devido à cirurgia, conforme suas dúvidas iniciais.

Assim, a fim de garantir a saúde do filho, a amamentação é continuamente qualificada pelas mulheres quanto à possibilidade ou não de cumprir esse propósito. A introdução de complemento, a progressiva oferta de maiores volumes de fórmula láctea, após a mamada, e por fim a opção pelo desmame são decorrentes desse processo de avaliação. Pelos dados 
apresentados, pode-se perceber que o desmame foi associado ao sentimento de frustração para as mulheres deste estudo.

Esse sentimento pode estar associado ao fato de que, em geral, a amamentação é percebida pelas mulheres como um processo natural e fácil, mas que nem sempre corresponde ao idealizado. O enfrentamento de dificuldades não previstas acarreta ansiedade e culpa por a mulher considerar-se incapaz de assegurar com seu leite a nutrição do filho (Nakano, 1996), 0 que, para as mulheres deste estudo, pode ser intensificado pelo fato de certa forma, ter a expectativa de que isso poderia ser provocado pelo procedimento cirúrgico.

Arantes (1991) explica que é transmitido um ideal de amamentação que gera na mulher uma expectativa em corresponder ao papel que lhe é atribuído. Se esse padrão ideal não se concretiza, um sentimento de frustração aflora na mulher.

\section{Buscando soluções para o volume insuficiente de leite}

Discurso do Sujeito Coletivo T2/DSC2:

"No hospital eu fui ao banco de leite para tentar com a bomba, ver se eu conseguia ativar, estimular. Eu estou tomando Plasil® também, comecei a tomar na semana passada. Eu estou tomando muito mais líquido e estou vendo que está refletindo bem na quantidade do leite, na produção do leite. Eu fico enchendo jarras e jarras de água para tomar e me manter bastante hidratada, tudo que puder ajudar na amamentação.

Eu tentei fazer acupuntura nas mamas. A acupuntura teve resultado bom na primeira semana, inclusive chegou a escorrer. Resolveu na primeira semana, eu achei que o leite desceu mais. Mas eu fiquei muito estressada e eles acharam que ia secar o 
leite. Aí meu ginecologista me deu para tomar alguns dias um remédio, que além de aumentar o leite, é também um antidepressivo e o pediatra entrou com complemento. Ele tinha pedido para ir dando na colherinha e eu não consegui fazer na colherinha. 0 copinho eu não recomendo para ninguém, ninguém. Dar complemento no copinho foi muito frustrante porque ele engasgava o tempo todo. Quando eu lembro meu nenê com aquele copinho e fazendo aquela bagunça, engasgando... foi assim um pesadelo. É traumático! Era uma coisa que eu até que queria, eu não queria ir já para mamadeira porque falavam que se ele pegar a mamadeira ele nunca mais vai querer peito.

Daí, depois a gente tentou usar a mangueirinha, mas também dava muito trabalho, quase que não dava tempo de limpar, esterilizar e amamentá-Io novamente. E ele ficando com muita fome, cada vez com mais fome, chorando mais e até o médico liberar a mamadeira com uma semana de vida foi bastante frustrante.

Eu sempre amamento antes e depois eu complemento com a mamadeira logo em seguida. É como se fosse uma muleta para mim porque eu sei que tem outra coisa, não depende só de mim. Isso me deixa mais calma e eu vejo que o leite aumenta. Isso aumentou minha produção. Eu sou muito nervosa, isso é um fator assim crucial para produzir, prejudica."

A identificação materna de que a quantidade ou qualidade do leite é insuficiente e de que o filho não está adequadamente alimentado, gera reavaliação da amamentação e ações para resolução do problema detectado (Silva,1997). 
As mulheres do estudo buscaram diferentes estratégias para aumentar a produção láctea ao considerar a quantidade de leite como insuficiente para as necessidades do bebê, já nos primeiros dias de amamentação, ainda durante a internação hospitalar.

O aumento da ingestão hídrica é uma prática consolidada a despeito da ausência de trabalhos científicos que comprovem sua eficiência. O emprego de medicamentos galactogogos também é um recurso freqüente e mais recentemente associado com antidepressivos. Por fim, as mulheres recorreram a outros métodos alternativos como a acupuntura. Nakano (1996) também observou em seu estudo que nas tentativas para reversão do quadro de baixa produção de leite, as mulheres ultrapassam as condutas medicalizadas e buscam outras estratégias.

Da mesma forma, como pode ser observado neste estudo, a oferta de complemento foi introduzida após a orientação do pediatra, pois, como afirma Nakano (1996), a prescrição do médico respalda a oferta do complemento para que a mulher não seja reprovada no seu meio social.

Ao iniciar a introdução de complemento, as mulheres, embora reconheçam a interferência da mamadeira no padrão de sucção do recém-nascido, vivenciam a dificuldade em ofertar a dieta por meio de colher ou no copinho, conforme a orientação do profissional da saúde. O uso de colher e copo para oferta de leite para lactentes não é o usual no nosso meio. Assim, as mulheres referiram dificuldades para a execução técnica do procedimento além de maior demanda de tempo. Com o temor do engasgo da criança durante a alimentação no copinho, as mulheres desqualificam essa via de administração buscando outra forma de oferecer o leite ao seu filho.

Pode-se inferir que, além das dificuldades operacionais relatadas pelas mulheres para 0 emprego destes recursos, há maior familiaridade com a oferta de leite em mamadeira, reforçada 
pela relação simbólica desse artefato ao universo do bebê. Essa forma de alimentação é freqüente e parece oferecer maior praticidade e segurança às mães.

Como comentado anteriormente, quando a pouca produção de leite está associada à fome e baixo ganho de peso, a amamentação passa a ter um significado de risco para a criança, o que pode provocar maior ansiedade materna. Assim, o uso de alternativas para alimentação da criança, além de significar uma segurança para o lactente, também suprime ou alivia a carga de responsabilidade materna em nutrir o filho por meio do aleitamento, minimizando sua ansiedade.

Dessa forma, para as mulheres deste estudo, a introdução do complemento alimentar mostrou-se também como um auxílio para ela, diminuindo o encargo de produzir leite na quantidade necessária para saciar a fome do filho e trazendo maior tranqüilidade nessa relação.

É interessante observar que as mulheres reconhecem que o estresse está relacionado com a baixa produção de leite e quando estão tranqüilas observam o aumento do volume de produção láctea. Almeida (1999) explica que o reflexo de ejeção apresenta um componente somático e pode ser inibido por estresse físico ou psíquico que a mulher vivencia durante 0 período de amamentação. Arantes (1991) observa que os manuais de aleitamento apregoam que as mulheres devem permanecer calmas e relaxadas. A autora pontua que orientar a mulher para manter a tranqüilidade é irreal, considerando que esse estado não se concretiza apenas com o simples desejo materno.

\section{A produção de volume suficiente de leite}

Discurso do Sujeito Coletivo T2/DSC3:

"Ele continua mamando no meu peito, sabe direitinho aonde ir e como pegar. Eu ainda estou amamentando, ainda está no peito direto, só está no peito. Exclusivo, nada 
de água, chá, nada. Está sendo supergratificante, porque eu tenho muito leite, bastante, tem de sobra. Eu sinto que a produção está supergrande, ele acaba de mamar, dá duas horas e se ele dorme muito aí começa vazar mesmo, precisa tirar até. Eu não estou tendo problema de leite, nossa, é muito. Você pode ver pelo tamanho dele, está crescendo super-rápido, mas enquanto não pesou, eu não relaxei. Eu quero ver a balança, isso que me interessa e está ganhando uma média trinta a trinta e quatro gramas por dia."

A literatura indica que a prática da amamentação tem pouca possibilidade de êxito em nutrizes com mamoplastia, mas, no grupo de mulheres do estudo, o aleitamento materno exclusivo foi relatado em ambos os tipos de cirurgia, embora em caráter de exceção, naquelas com mamoplastia redutora.

Os motivos que levam a mulher a amamentar estão relacionados com o valor atribuído ao leite materno que garante o desenvolvimento saudável da criança. Considerando que o papel materno é percebido como cuidar do filho, a nutriz considera que seu leite está protegendo a criança (Silva,1997).

A capacidade de produzir leite e de amamentar tem um significado especial para a mulher e seu meio relacional, indicando seu valor como nutriz e a qualificando socialmente como mãe (Nakano,1996).

"A amamentação é vivenciada como uma função social que dá ao corpo feminino o status de corpo materno, naturalmente dócil, abnegado e sujeito a sacrifícios por sua cria. As mulheres 'desejam' amamentar por reconhecerem que através desse ato estão dando 'o melhor para o filho' em detrimento dos sacrifícios que tal prática possa lhes acarretar já que o prazer está no 
reconhecimento de serem 'responsáveis' pelo bom desenvolvimento e estado de saúde da criança" (Nakano, 2003, p.104).

No processo de avaliação materna da sua capacidade de amamentar, as mulheres analisam a quantidade de leite atual em comparação com aquela que tinham expectativa de produzir. Consideram boa produção quando há drenagem espontânea de leite ou quando a criança não é capaz de esgotar todo o volume produzido (Silva,1997).

Da mesma forma, essas mulheres avaliam a amamentação, considerando o desempenho do lactente na mamada, a habilidade de pega e sucção na mama, associado à constatação da abundante produção de leite, confirmada pelo vazamento espontâneo de leite e a necessidade de ordenha para evitar o ingurgitamento. Nessa avaliação também consideram aspectos do comportamento do lactente, como o padrão de sono, e o ganho de peso, o que também foi observado neste estudo.

Mesmo nas situações em que produção de volume satisfatório de leite seja evidente, percebe-se que a amamentação das mulheres com mamoplastia de aumento ou redutora traz ansiedades, uma vez que estas mantêm uma monitoragem constante do peso do lactente para assegurar-se que a amamentação exclusiva não oferece risco ao bebê. Silva (1997) constatou que a perda ou ganho de peso do lactente quando não corresponde à expectativa materna é percebido pela mulher como um indicador que o filho não está bem alimentado e, portanto, a amamentação assume simbólica e concretamente um significado de risco para a criança. 


\section{Enfrentando os desconfortos da amamentação}

Discurso Sujeito Coletivo T2/DSC4:

"No hospital já estava começando a doer, eu já senti um pouco de dor. Deram na maternidade aquele bico de silicone. Nossa, que coisa horrível aquilo, aumenta a fissura, vira um horror. No banco de leite ela colocou aquele sugador e eu quase morri. Machucou, acabou de machucar meu seio. Meus seios ficaram com bastante rachadura, apesar [bebê] dele pegar bem, dele ter uma ótima pega. Eu achei que ia perder o mamilo porque ficou todinho na carne viva os dois, me arrebentou o peito. Doía muito para amamentar. A dor do mamilo é gigante, as primeiras sugadas... é de não pensar em outra coisa, a não ser naquela dor. Quando ele estava mamando chegava a sangrar. Nesses dias que estavam piores, eu queria subir as paredes de dor, morrer. Como ele mamava muito, não dava tempo de cicatrizar. Sabe quando você tem vontade de desistir de amamentar? Você fala 'não é possível!'. Eu ficava exausta. Então eu não gostei nada daquela experiência. Eu sofri muito nas primeiras duas semanas por causa de dor. Eu só tenho coragem de sentir aquela dor por um filho.

Eu usei aquela pomadinha que eles entregaram na maternidade, tentei pegar sol, secador depois do banho para secar e luz infravermelha para cicatrizar. Usei aquela concha. Pelo menos não encostava, se eu punha aquele protetor, grudava e daí na hora que tirava, saía casquinha.

Eu dei mamadeira para ele por causa do mamilo machucado. Acabei dando mamadeira para ele, mas para poupar meu peito. Fiquei um tempinho 
sem dar a mama direita, dava mais a esquerda aí foi melhorando, fui voltando e aí logo cicatrizou. Eu sinto muita dificuldade neste lance da amamentação, eu fico confusa. A gente que quer amamentar tem que se esforçar, porque não é fácil. O que a gente estuda, na prática não funciona.

Agora no período noturno, na madrugada, eu nem ofereço a mama porque a mamada é tão longa, porque até dar a mama e depois dar a mamadeira...senão eu não durmo. A noite eu não amamento, eu só ofereço a mamadeira mesmo porque eu percebi que o que eu preciso é dormir. Então ele toma na mamadeira. "

O processo de aleitamento das mulheres deste estudo, a exemplo do encontrado por Silva (1997), também pode ser vivenciado por inúmeros desconfortos originados por intercorrências do processo lactacional e na amamentação. No DSC acima apresentado, percebe-se a dor como um dos primeiros sinais de desconforto.

$\mathrm{Na}$ tentativa de resgatar a integridade da região mamilo-areolar e evitar a dor, as mulheres recorreram a diversas estratégias para a cura dos traumas mamilares e tratamentos, nem sempre com comprovada eficácia.

Neste estudo, as mulheres referem dor e traumas mamilares no período inicial de amamentação e sofrimento pessoal com essa experiência, havendo a referência de que a dor era intensificada durante as mamadas devido à sucção do recém-nascido, provocando o que foi descrito por elas como um sofrimento intenso capaz de induzir à interrupção da prática do aleitamento. 
Dessa forma, fica evidente que elas também procedem à avaliação de suas condições para amamentar, considerando o sentimento de sofrimento e prejuízo à sua saúde e bem-estar provocados pelas intercorrências como os traumas mamilares e ingurgitamento mamário. Dependendo da extensão da lesão e do grau de dificuldade das mulheres em superar estas dificuldades, isso pode constituir um fator de desmame por fazer a vivência da amamentação ser percebida como uma experiência negativa e difícil (Silva, 1997). Em estudo qualitativo, conduzido por Ramos, Almeida (2003) das alegações maternas para o desmame, as intercorrências mamárias, como trauma mamilar, dor e ingurgitamento surgiram como um fator interveniente na amamentação.

A dor decorrente dos traumas mamilares são aspectos subestimados pelos profissionais da saúde e pouco explorados em literatura.

A banalização da dor e a não consideração dos sentimentos das mulheres pela equipe de saúde, revelaram como fatores de desmame (Ramos, Almeida, 2003). Arantes (1991) observa que os discursos dos profissionais da área da saúde, que tencionam incentivar a amamentação, destacam alienadamente somente os aspectos positivos, e que se deve considerar que a prática de negar as facetas negativas não contribui para aumentar a adesão ao aleitamento.

Para as participantes deste estudo, o trauma e a dor foram elementos desencadeantes para introdução de complemento como forma de resgatar a saúde e bem-estar da mulher e propiciar, mesmo que parcialmente, a continuidade da amamentação, ou de alívio total, em detrimento do aleitamento, provocando o desmame.

Pelo discurso apresentado é possível observar que na percepção das mulheres deste estudo, a trajetória da amamentação pode apresentar-se com dificuldades que exigem esforço 
pessoal para estabelecer sua prática. Nakano (1996) menciona que essa experiência é muitas vezes idealizada e nem sempre condiz com a sua prática. 


\section{TEMA 3. Reflexão sobre a interface da cirurgia com o processo da amamentação}

As mulheres deste estudo, também buscam avaliar qual o grau de comprometimento da mama e do processo de amamentação que poderia ser provocado pela cirurgia. Observa-se que quando as mulheres vivenciam dificuldades, em especial representadas pela baixa produção de leite, acreditam que a cirurgia interferiu negativamente na lactação, confirmando suas suspeitas de que os procedimentos foram lesivos à suas mamas. Nos casos que a amamentação é implementada com sucesso e que o volume de leite esperado está presente, as mulheres isentam a mamoplastia, não considerando que possa ter havido prejuízos funcionais ou estruturais para a mama, o que é possível compreender observando os discursos compostos e apresentados nesse TEMA. Da mesma forma, os efeitos da amamentação sobre a estética das mamas, também têm seu lugar na reflexão dessas mulheres, que, embora elas não tenham indicado ser este fator um elemento decisório para a trajetória da atual prática de amamentação, também não excluem a possibilidade de correções estéticas futuras, se necessário.

\section{Julgando que a cirurgia não interferiu na amamentação}

Discurso do Sujeito Coletivo T3/DSC1:

"A princípio não interferiu em nada, acho que não afetou em nada. Não senti nada de diferente, correu normalmente. No meu caso sai uns jatinhos, eu acho que está funcionando tudo direitinho. Eu estou com bastante leite, ele está mamando bem. Eu não sei se alguém tem algum problema, mas não existe eu acho, nenhuma interferência. Está tudo certo." 
Assim, houve mulheres deste estudo que não perceberam dificuldades de produção e ejeção do leite, conforme abordado anteriormente, o que as fez considerar que a mamoplastia não interferiu na estrutura da glândula mamaria e conseqüentemente na lactação, tendo sido preservada a funcionalidade da mama, o que pode ser confirmado pela visualização da saída de leite.

Dessa forma, algumas mulheres, tanto com mamoplastia redutora como de aumento, tiveram a oportunidade de vivenciar a amamentação como uma prática prazerosa para si e para 0 filho.

\section{Tendo prazer em amamentar}

Discurso do Sujeito Coletivo T3/DSC2:

"Eu não podia estar mais satisfeita, é uma coisa que eu gosto de fazer. Eu vou tentar o máximo possível, não tenho prazo para parar. Depois que passa a primeira semana vira prazeroso. Aquela sensação de teu filho está vivendo, está crescendo por tua causa... é uma relação de dependência mas totalmente saudável. Você está dando subsídio para ele crescer. A sensação de alguém depender de você é muito legal, de você poder fazer o bem para alguém cem por cento, é muito legal. Talvez tenham pessoas que se satisfaçam com outro tipo de dependência, mas essa dependência do filho crescer porque você está dando a oportunidade através do leite é muito boa. 0 prazer de amamentar é muito bom, da gente saber que a criança depende só do seu leite é o máximo. Graças a Deus, deu tudo certo." 
O DSC confirma que para as mulheres deste estudo que conseguiram superar os primeiros desconfortos da amamentação, não encontraram dificuldades quanto ao volume de leite produzido e mantiveram o aleitamento, expressaram vivenciar essa experiência com prazer. A possibilidade de vivenciar a amamentação em sua plenitude, como experiência agradável, proporciona o sentimento de satisfação por perceber-se importante e agir ativamente no desenvolvimento e bem-estar do filho. A percepção de dependência que a criança tem dos cuidados da mãe, quando há prazer na amamentação, é traduzida por um sentimento de valorização do papel materno, sendo como elas mesmo referem, "uma dependência saudável", quando a nutriz é capaz de suprir as necessidades da criança com seu leite.

Esse aspecto também foi constatado por Arantes (1991) ao ver que a mulher pode considerar a amamentação como uma experiência agradável decorrente da oportunidade de maior contato físico e afetivo com o filho, da mesma forma que em seu estudo Nakano (1996) observou que as mulheres sentiam-se gratificadas ao amamentar por proporcionar benefícios ao filho.

A mulher pode vivenciar a amamentação "achando natural", como algo próprio da maternidade decorrente de seu papel de mãe. O prazer de amamentar está relacionado à percepção que a mulher tem que seu filho está bem nutrido, saudável. Nesta situação, a mulher associa um valor ao seu leite e sente orgulho de desempenhar bem seu papel de nutriz e de mãe. A mulher é estimulada a continuar a amamentar quando interpreta o comportamento do filho de forma positiva e considera que está adequadamente nutrido (Silva,1997).

Percebe-se neste estudo, pelo discurso acima, que as mulheres que estavam amamentando na ocasião da entrevista, a despeito das dificuldades iniciais já superadas, referiram grande satisfação por constatar que o crescimento saudável do filho é decorrente da 
amamentação. A relação mãe-filho que se estabelece é fortalecida, valorizada e considerada benéfica para a criança. A gratificação é percebida de forma tão positiva que 0 desejo de perpetuar essa sensação não define prazo para o desmame.

A ansiedade que estava presente na gestação e no início do período de amamentação nas mulheres, com mamoplastia redutora ou de aumento, é substituída pela sensação de alívio, à medida que o aleitamento se desenrola de forma satisfatória, conforme a percepção materna.

\section{Julgando que a cirurgia prejudicou a amamentação}

Discurso do Sujeito Coletivo T3/DSC3:

"A mamoplastia atrapalha um pouco, não sei em que grau, dependendo da mamoplastia, mas sempre atrapalha um pouco na amamentação. Como muda um pouco a mama, eu acho que interfere na amamentação e eu não queria que tivesse acontecido. Eu acho que os ductos estavam meio interrompidos. Quando corta o mamilo, corta os ductos também. Eu sentia aquele leite descer, eu sentia aquela coisa quente, todos os sintomas de que eu tinha leite só que ele não saía. Só que o problema eu acho que não foi só a saída do leite que ficou complicada com a cirurgia, mas também até a própria produção. Eu cheguei a alugar uma bombinha para ver o quanto de leite saía do meu peito e fiquei bastante frustrada de ver que não estava saindo muito. Quando eu tirava leite na máquina ou mesmo manual eu via que saía só de dois ductos, e eu sempre pensava, isso é coisa da cirurgia, deve ter interrompido, não sei. Agora eu não sei se está relacionado com a mamoplastia, mas desta vez o bico rachou todo, agora que está parando de doer." 
À medida que as mulheres deparam com dificuldades, buscam uma relação de causa e efeito para o que está acontecendo. Relacionam o pequeno volume e a dificuldade da ejeção do leite produzido com a cirurgia plástica e são capazes de descrever, de forma simplificada, o que consideram ser as interferências na estrutura da glândula mamária.

As mulheres observam que há produção do leite em suas mamas, mas constatam que não há extravasamento, provavelmente devido ao corte e interrupção dos ductos. Também, podem perceber que além das dificuldades da ejeção, há comprometimento da produção do leite. Ambas situações descritas e manifestadas pelas mulheres já foram exploradas por alguns estudos científicos que abordam as implicações das mamoplastias na lactação e trazem essas evidências que foram comprovadas, na prática por essas mulheres.

Quando as mulheres têm a percepção da interferência da cirurgia na amamentação, buscam confirmar a baixa produção ou ausência de ejeção espontânea, por exemplo, com a extração do leite com bomba para quantificar o volume produzido, atribuindo as dificuldades de produção e ejeção à mamoplastia.

A fragilidade do tecido da região mamilo areolar no decorrer da amamentação, também é observada, embora não afirmem a correlação com a cirurgia plástica.

\section{A culpa e 0 arrependimento}

Discurso do Sujeito Coletivo T3/DSC4:

Quando o processo de amamentar se realiza com prazer, pelo fato de a mulher ter conseguido superar dificuldades iniciais ou mesmo tardias e alcançado seu objetivo de aleitar o filho, exclusivamente ou mesmo que parcialmente, os receios relativos aos efeitos da cirurgia nas 
mamas se dissipam, à medida que a amamentação evolui, desde que considerada satisfatória para ela e seu filho.

Por outro lado, quando as mulheres que vivenciam dificuldades na amamentação, não conseguem superar os obstáculos e manter o aleitamento materno de forma exclusiva ou mesmo parcial, elas atribuem as causas do insucesso de amamentar à mamoplastia, questionam a validade de ter se submetido à cirurgia, manifestando sentimentos de culpa por terem, segundo sua visão, mesmo que não intencionalmente, provocado a situação atual.

Discurso do Sujeito Coletivo:

"Na minha cabeça passa assim um arrependimento de eu ter feito essa cirurgia. Quando eu tive que entrar com complemento, eu fiquei superchateada, tinha certeza que era por causa da cirurgia. Eu entrei em depressão porque não eu consegui amamentar. O que me consola é que eu sei que muitas outras mães que não fizeram cirurgia nenhuma também tem problema de amamentação.

A gente tem que desencanar porque senão a gente se sente muito culpada. 0 que eu queria era poder oferecer mais o leite materno ao meu filho do que eu pude. Então eu gosto de pensar que talvez a dificuldade que eu tenha tido, não seja especificamente só da operação e que futuramente, em outra oportunidade, eu possa vir a amamentar normalmente. Hoje você pára até para pensar se realmente vale a pena, eu não sei se eu operaria de novo. É um conselho que eu vou dar para você, não faça se você quer amamentar. Eu não faria hoje, de jeito nenhum, não faria mesmo. Se falasse pode ser que corte algum canalículo, pode ser que diminua sua produção de leite, eu não teria feito. 
Por outro lado, eu não consegui amamentar, mas consegui suprir de outra maneira. Eu quis eu mesma cuidar dele, eu que cuido mesmo dele. Como ele está na mamadeira, eu procuro sempre estar nas horas das mamadas, porque eu acho que é um momento muito importante mesmo não tendo o peito, procuro ter essa relação com o nenê, mesmo sendo na mamadeira. Eu sou mãe de outra maneira, não sou mãe de peito. Eu sou mãe, mãe. Ser mãe não é amamentar, ser mãe é outra coisa, é uma coisa totalmente diferente."

Assim, percebemos que para as mulheres deste estudo, a necessidade da introdução de complementação e a conseqüente progressão para o desmame são relatados com pesar. 0 insucesso da sua prática de aleitamento materno é carregado de arrependimento e sentimento de culpa de ter realizado o procedimento cirúrgico sem ter refletido sobre 0 assunto e pode desencadear sintomas depressivos. Como um consolo, as mulheres procuram comparar as situações que vivenciam com a de outras mulheres, que mesmo não tendo sido submetidas à mamoplastias também não conseguiram amamentar. Esse fato reforça a esperança, manifestada por essas mulheres, de que o padrão de aleitamento insatisfatório que enfrentam, pode não ser proveniente ou causado diretamente pela cirurgia, o que as remete à construção de uma expectativa de melhor resultado para experiências futuras.

Cientes dos benefícios do aleitamento no vínculo mãe e filho, essas mulheres procuram fortalecer a ligação com a criança de outra forma, assumindo todos os cuidados com o bebê mesmo podendo dispor de outras pessoas para auxiliar na alimentação da criança e em outras tarefas. Expressam assim, que procuram compensar a ausência da amamentação suprimindo as necessidades integrais da criança, desdobrando-se em cuidados com o filho e mantendo-se 
presente. Dessa forma, as mulheres deste estudo que não puderam manter a amamentação, demonstram uma necessidade de qualificar o papel materno para além do processo de amamentar, sendo esta prática, considerando a sua visão, uma parcela do que representa ser mãe, pois "ser mãe não é amamentar, ser mãe é outra coisa", ampliando assim um entendimento maternidade que deveria ser melhor explorado e valorizado em nossa sociedade. Fica evidente a necessidade de essas mulheres acreditarem que a prática da amamentação não pode resumir toda a sua existência, pois para elas, esta pode ser uma experiência que não será recuperada, devido ao caráter definitivo da lesão em suas mamas, resultado da cirurgia que elas optaram por fazer.

Considerando os resultados do estudo de Silva (1997), a qual relata que para as mulheres, as conseqüências do aleitamento na estética da mama pode ser um fator de importância capaz de prejudicar a intenção de amamentar, investigamos junto às mulheres deste estudo, como elas viam a possibilidade da amamentação alterar ou prejudicar os resultados estéticos obtidos pela cirurgia, o que pode ser compreendido pelo DSC abaixo:

\section{Se precisar, eu faço outra}

Discurso do Sujeito Coletivo T3/DSC5:

"Quanto à amamentação prejudicar a cirurgia que fiz, não me preocupei com a parte estética, não. A cirurgia é a última das minhas preocupações. Nunca pensei nisso, de jeito nenhum, isso nunca me passou pela minha cabeça. Eu estava tão feliz de ter esse filho! Eu só fiquei preocupada com o contrário, que a mamoplastia interferisse na amamentação. Nunca preocupada com o peito, preocupada assim com ele, de conseguir amamentar. 
Apesar de que eu acho que alterou a mama, mas paciência isso nunca me incomodou não. Eu acho que é uma conseqüência de todas as mulheres, que a amamentação cai, cai... Eu acho que se alguém quer fazer e quer ter outro filho, espera para fazer. Se for por vaidade, espera. Porque realmente não segura, o peito cai do mesmo jeito. O peito fica diferente depois, mas eu acho que é uma opção.

Eu acho que hoje, com a cirurgia plástica, depois você repara, depois arruma, mas eu acho que o prazer de dar, de amamentar é... Se precisar eu faço outra, não tem problema. Já que eu já fiz uma vez e foi supertranqüilo, se alterar eu faço de novo, eu não tenho nenhum problema quanto a isso. Meu marido é que fala, vem com certificado de garantia, estragou a gente devolve para retocar."

As mulheres deste estudo, embora tenham manifestado mesmo que tangencialmente suas opções de mamoplastia pela necessidade de melhorar esteticamente suas mamas, negaram que esse tipo de preocupação seja prioritário quando confrontado com o desejo de amamentar e as necessidades da criança.

Assim, percebe-se que, para as mulheres que buscaram a cirurgia plástica por estarem insatisfeitas com a imagem corporal, a preocupação com a preservação das mamas não é um fator a considerar na decisão de amamentação.

O bem-estar da criança apareceu como elemento prioritário para essas mulheres, ocorrendo uma mudança de interpretação e de valorização do corpo materno. As mamas, anteriormente símbolo da feminilidade e beleza, passam a ser um símbolo da maternidade, sendo o papel materno compreendido por elas como de doação em prol do bem-estar do filho. 
Pode-se perceber que as questões da imagem corporal são pouco significativas em comparação às necessidades da criança, revelando o desvalor do corpo materno, cujo significado é inferior ao corpo do filho (Nakano,1996).

No entanto, as mulheres acreditam que o aleitamento tem interferências e citam a ptose mamária como uma condição esperada do ser mãe. Essa crença também foi relatada pelas mulheres em estudo conduzido por Nakano (1996) que também observou que as conseqüências da amamentação pode ser um fator de preocupação com a imagem corporal para a mulher e gerar sentimentos de insegurança por sentir-se menos atraente em seus relacionamentos.

Dessa forma, é possível notar que as mulheres relatam que percebem que as mamas sofrem alteração de sua forma com o aleitamento, mas no momento esse não é um aspecto valorizado. Embora neguem a preocupação com a estética, esta parece estar latente, uma vez que consideram a programação de nova cirurgia se julgarem necessário.

A possibilidade de submeterem-se novamente à mamoplastia reforça a facilidade de acesso e a percepção das mulheres da simplicidade de tal procedimento, ainda, evidencia-se a banalização do corpo feminino que no discurso acima se vê representada na referência do "certificado de garantia" e na "devolução", como se a mulher fosse um objeto ou um bem de consumo e seu corpo pode ser submetido a retoques para uma construção estética de acordo com os ditames da sociedade.

Embora os resultados desse estudo tenham sido organizados em temas que agruparam os DSCs que estavam articulados entre si, optamos por apresentar um DSC que pareceu se constituir em um tema muito expressivo e que pode permear os demais. Ele trata de uma reflexão da mulher que vivencia a maternidade com a interface de seus anseios pessoais, 
individuais, mas que está sujeita ao sufocamento que a sociedade impinge às mulheres sem thes dar voz ou ouvidos, testemunho vivo de que ainda hoje as mulheres convivem com o autoritarismo da sociedade, em suas relações de cliente e profissionais e mesmo, num modelo patriarcal que subjuga a mulher a dependência da família se quiser exercer a sua maternidade plenamente. 


\section{TEMA 4. Conciliar o papel de mãe, nutriz e mulher - não é fácil}

\section{Discurso do Sujeito Coletivo T4/DSC1:}

"Não é fácil. A pessoa estuda, se estabelece profissionalmente e depois tem filho. É difícil a mulher olhar para trás e falar tchau para tudo isso que agora eu vou me dedicar, optei por outra coisa na minha vida. Tem que ter muita coragem para fazer isso. É difícil. Minha vida inteira, desde que eu me formei, eu não pedi mais um tostão para ninguém, a partir de hoje, para eu comprar uma calcinha eu tenho que usar o dinheiro dele. Eu nunca tive tão pouco tempo para mim, nunca dormi tão pouco na minha vida, quase não sobra para a gente. É complicado, mas dá, vale a pena.

O meu pequeno fez dois anos e eu também quero estar um pouco com ele, tem algumas coisas que eu quero levá-lo. Não quero, não gosto de deixá-lo, não consigo. Nunca deleguei ele para ninguém o dia inteiro, ele também é importante.

Quando eu estou sentada aqui dando de mamar, eu não posso fazer nada. Uma pessoa supercapacitada falou para mim o seguinte 'a sua prioridade agora deveria ser amamentar'. Eu falei para ela 'você já teve filho? É uma decisão da mulher, eu amamento, eu quero amamentar porque se eu não quisesse eu não estava amamentando. Você não tem o direito de falar isso para uma mulher'. Ela ficou indignada comigo, e falou 'sinto muito por você é só o que eu posso te dizer'. Que é isso! Enlouqueceu!

A minha cunhada tem um médico ginecologista que disse assim para ela 'só não tem leite a mulher que não quer'. Ele fala isso. Manda ele fazer leite para dar de mamar. Sabe, as pessoas parecem que às vezes não têm sensibilidade e para uma mãe de primeiro filho mata. Você já tá emocionalmente abalada, aí vem uma dessa, você quer 
morrer, porque você se sente a pior das piores mães. Por isso eu acho que você tem que respeitar. Se a mãe não quer amamentar, paciência, se ela não pode, não quer, não consegue ou morre de dor, a criança vai ser saudável, a gente sabe, graças a Deus. Hoje em dia, a gente sabe, você consegue suprir as necessidades. Eu acho que é maravilhoso amamentar, mas também se não dar, não vejo mal também, de não amamentar. É legal amamentar, lógico que é, mas não é vital."

A maternidade trouxe mudanças significativas na vida das mulheres com necessidade de reorganização de suas atividades profissionais e pessoais. A inserção da mulher no espaço público implicou em alterar papéis, perder conquistas para ganhar novos espaços, sem contudo, desvincular-se dos papéis tradicionais e de certa forma, cobrados pela sociedade. A opção, por desempenhar e conciliar uma vida profissional com os atributos "naturais" agregados ao papel feminino, pode ser acompanhada de sentimentos conflituosos, como a alegria com a chegada do filho e resignação com as perdas de espaços já ocupados fora do ambiente privado.

Percebe-se no DSC acima as dificuldades que as mulheres têm em atender às solicitações dos demais membros da família, especialmente dos outros filhos, quando procuram manter o mesmo padrão de cuidados e atenção. A opção pela maternidade parece não ser feita sem conflitos uma vez que gera a ambigüidade de sentimentos acarretada pela perda da independência e liberdade, quando a mulher se percebe tendo que se dedicar integralmente à família e depender economicamente do outro.

As mulheres apontam a falta de tempo e espaço para si mesmas decorrente da demanda exigida pela criança em seus cuidados diários. Silva (1997) observa que as mensagens relativas à amamentação apelam aos sentimentos maternos e parecem não respeitar as necessidades 
das mulheres. As ações em prol do aleitamento têm como foco o bem-estar do lactente pressionando as mulheres e revelando a mensagem da obrigatoriedade em amamentar, reforçando o papel materno em detrimento dos demais papéis que a mulher desempenha em sua vida.

Nakano (1996) esclarece que a amamentação, considerada um atributo da maternidade, pode ser vivenciada como uma prática conflituosa, considerando que a mulher tem a necessidade de se adequar e conciliar com os múltiplos papéis sociais que assume. A mulher, além de ser avaliada como boa mãe, deve ser capaz de manter seu desempenho em suas outras atribuições, exigindo de si um desdobramento para suportar a sobrecarga de atividades. 0 desgaste é inevitável e causa sentimentos de incapacidade e conflitos nas relações familiares e sociais.

No conteúdo desse DSC, as mulheres expressam sua percepção sobre a atitude dos profissionais que é vista como autoritária e impositiva em especial no que concerne ao aleitamento materno, visto e reiterado como uma obrigação materna, sem que se considere as condições individuais de cada mulher.

A pressão do grupo social e dos profissionais da saúde para a mulher amamentar, cumprindo seu papel de mãe, é claramente percebida pelas mulheres e gera sentimentos de indignação, revolta e exigência de respeito aos seus desejos e limitações.

Assim, é possível perceber que sentimentos ambíguos de desejo e fardo acompanham o processo de amamentação, incluindo a própria maternidade. A valorização da prática do aleitamento e o reconhecimento social que dela se advém contrapõem as dificuldades enfrentadas pela mulher. $\mathrm{O}$ discurso ideológico em prol do aleitamento dificulta que as mulheres tomem consciência da falta de estruturas de apoio para que iniciem e mantenham o aleitamento 
(Nakano,1996). A experiência de amamentação se processa em conflito nos limites de ser "0 corpo para si" e o "corpo para o filho". O corpo materno é sujeito às solicitações da criança e as mulheres tendem a priorizar as necessidades do corpo do filho. A mulher nem sempre se coloca na posição de objeto da criança, assumindo o "corpo para si" e evidenciando a valorização de si nesta relação.

Observamos que as mulheres deste estudo, expressam que existem limites para a solicitação e exigências do cuidado da criança em detrimento do bem-estar materno, e nas condições que estas mulheres apresentam, com prejuízo de funcionalidade de suas mamas, os limites não estão impostos e definidos apenas por elas, que já pagam um alto preço pela culpa que carregam em ter provocado, mesmo que não intencionalmente, a dificuldade de manter a amamentação de seus filhos. Assim, a valorização da amamentação é relativizada, mediante a percepção que a mulher tem de sua condição e possibilidade de amamentar, seja pela baixa produção de leite, seja pela sua dificuldade de superação de demais intercorrências para manter a amamentação. Nesse sentido, ao expressar a sua impossibilidade ou dificuldade de implementar a amamentação, mediante o uso de alternativas que elas consideram seguras para a saúde da criança, o aleitamento deixa de ser vital passando a ser uma possibilidade dependente das condições maternas.

Esse DSC demonstra a dificuldade de conciliação do papel materno com demais papéis que a mulher assume na sociedade, mas traz também um dado significativo que se traduz no apelo da mulher sentir necessidade de ser vista como uma pessoa e não na sua relação direta de ser mulher e sua capacidade reprodutora. 


\section{CONSIDERAÇÕES FINAIS}

As transformações sociais com a valorização excessiva do corpo submetem especialmente as mulheres a procurar recursos cosméticos e cirúrgicos para garantir a adequação da sua imagem aos padrões vigentes. Os avanços nas técnicas das cirurgias, associados à aceitação social desses procedimentos, contribuíram para a progressão do contingente de mulheres que, objetivando conquistar uma melhor aparência, recorrem à mamoplastia redutora ou de aumento.

Apreende-se neste estudo que as mulheres vivenciaram dificuldades emocionais decorrentes da vergonha das mamas, as quais avaliaram como inadequadas devido ao tamanho excessivo ou reduzido quando compararam com os padrões vigentes, e recorreram à cirurgia. No momento da opção cirúrgica, as possibilidades de lactação no futuro nem sempre foram discutidas e consideradas em seu potencial. Os níveis de satisfação com os resultados cirúrgicos foram elevados e 0 aspecto da cicatriz representou o qualificador mais importante.

Os artigos científicos anteriormente apresentados, esclarecem que as alterações na estrutura da mama são dependentes do tipo de cirurgia, da habilidade e da técnica empregada com implicações, em graus variáveis, na estrutura da glândula mamária e impossibilitam um prognóstico preciso quanto às possibilidades futuras de aleitamento.

Neste estudo observamos que no período gravídico-puerperal, essas questões tornaram-se evidentes, quando as mulheres, em suas fases de gestantes e, posteriormente nutrizes, expressaram suas preocupações no momento em que a amamentação é ponderada como a forma de alimentação do filho e desconhecem qual o possível desempenho de suas mamas, principalmente quanto à capacidade de produção de leite. 
As mulheres realizaram um movimento em busca de informações sobre suas reais possibilidades em aleitar considerando a experiência de outras mulheres e dados em literatura, mas não encontraram respostas precisas nessas averiguações.

Concordamos com Silva (1999) ao afirmar que, embora a amamentação esteja presente no imaginário das mulheres a longo da gestação, é na situação vivida que seu curso é definido.

As mulheres, deste estudo, ao vivenciarem a amamentação, avaliaram a capacidade de produzir leite em quantidade apropriada às necessidades do filho, observando sinais da glândula mamária e fatores comportamentais do recém-nascido, em especial o choro. Silva (1999) esclarece que a mulher avalia sua capacidade de amamentar, ou seja, ter leite em quantidade e qualidade, pois assume o papel de provedora da criança. Nesse processo, a mãe observa a linguagem do filho e ao considerar que ele não está adequadamente nutrido, reavalia o curso da amamentação.

Esses aspectos foram manifestados pelas mulheres deste estudo e centraram especialmente sua avaliação no volume do leite, preocupadas que este poderia ser insatisfatório pesando o risco que isso poderia significar para o bebê. Dessa forma, recorreram a estratégias para aumentar a produção do leite e minimizar efeitos de aplicação de outros métodos de oferta de alimentos no padrão de sucção da criança. Quando não foi possível obter a reversão do quadro iniciaram a complementação láctea.

O complemento aparece como um benefício e estratégia de auxílio à mulher para prolongar a amamentação, oferecendo primeiramente a mama. Consideraram que 0 fato de contar com a oferta de fórmula, aumentou a tranqüilidade e reduziu a ansiedade materna decorrente da expectativa de ser a responsável em garantir a integridade da criança por meio de sua própria produção de leite. 
A oferta de complemento também foi considerada pelas mulheres como um auxílio na recuperação dos traumas mamilares. As intercorrências mamárias e a dor foram fatores estressantes no curso da amamentação e, embora suportados por períodos prolongados, ainda assim foram desencadeantes da complementação da dieta do recém-nascido.

Silva (1996) esclarece que as ideologias presentes nas campanhas de incentivo ao aleitamento, transparecem ser este uma forma natural para alimentação da criança ao considerar como resposta biológica e instintiva da mulher e sustentada em seu amor materno. Nas campanhas não são abordadas as dificuldades do processo e as questões sociais e culturais presentes no universo da mulher não são consideradas. Argumentos em prol do aleitamento associam a obrigação natural de amamentar com o dever sagrado de mãe sem respeitar as necessidades da mulher.

A filosofia dessas campanhas se origina no movimento higienista, iniciado no século XIX, que elaborou a construção social da amamentação e a modulação do comportamento materno. Observamos a manutenção dos mesmos mecanismos de controle social, por assim dizer, quando reduzem a mulher ao seu potencial reprodutivo e a amamentação, a um processo biológico, natural e próprio nos animais, imputando unicamente a mulher a responsabilidade do sucesso da amamentação para garantir a saúde do seu filho (Almeida,1999).

Neste estudo observa-se a utilização do complemento e da mamadeira no curso da amamentação das mulheres com mamoplastia. Esse recurso foi empregado na recuperação dos traumas mamilares possibilitando, após a recuperação das lesões, o retorno à amamentação. Também foi utilizado após as mamadas de forma a possibilitar que a criança recebesse o leite materno e fosse saciada com o volume restante do complemento. As mulheres com mamoplastia empregaram essa estratégia para prolongar o tempo de amamentação e postegar o desmame. 
Em contraste com estudos de Nakano (1996), as mulheres não verbalizaram as propriedades do leite humano e os benefícios do aleitamento como determinantes em sua opção e preocupação por amamentar. Silva (1997) destaca que a intenção de amamentar é sustentada no conhecimento sobre os atributos e benefícios do leite materno. Possivelmente o grupo de mulheres entrevistadas não relatou os atributos do leite humano como fator de destaque em sua opção, porque esses conhecimentos estão consolidados devido ao alto grau de escolaridade e acesso às informaç̧ões dessas participantes.

O aleitamento exclusivo foi observado em caráter de exceção no grupo de mulheres com mamoplastia redutora que em geral necessitaram ofertar volumes significativos de fórmula láctea ao filho ou desmamaram. O aleitamento materno foi o método de alimentação de metade das mulheres com prótese mamária e nas demais aleitamento exclusivo. Embora essa observação não tenha se constituído em objeto de nosso estudo, nem tenhamos dados conclusivos sobre a questão, vale a pena salientar, que esses dados nos levam a inferir que a mamoplastia redutora parece ser mais comprometedora da amamentação.

As mulheres relacionaram a cirurgia com a amamentação e, em sua maioria, acreditaram que a mamoplastia interferiu na lactação, pois observaram a dificuldade de ejeção e a produção reduzida, descrevendo de maneira suscita as alterações que imaginam na estrutura da glândula mamária. Apresentam pesar pela incapacidade de amamentar de forma exclusiva e pela proximidade do desmame. Sentimentos de culpa afloraram por terem optado pela cirurgia em uma época anterior de suas vidas.

A comparação da experiência atual com a de outras mulheres foi um recurso empregado pelas mulheres para reduzir os sentimentos negativos pela opção cirúrgica e minimizar 0 
sentimento de culpa, pois concluem que a amamentação é uma experiência única e com resultados individuais.

As mulheres expressaram insatisfação com o auxílio e apoio que esperavam obter da equipe de saúde. Silva (1999) observa que, embora os profissionais reconheçam o cenário de emoções e amplitude que cerca a experiência de amamentar, não conseguem incorporar essas questões em suas ações assistenciais. A atuação dos profissionais, sob a perspectiva da nutriz, é considerada autoritária, e essa atitude impede uma relação igualitária e franca (Silva, 2000).

Raramente é explicitada à mulher que intenciona amamentar o risco de insucesso devido à incapacidade da glândula mamária em produzir leite em quantidade suficiente para atender às necessidades nutricionais do recém-nascido, como resultado possível da cirurgia. Ocultar essa informação sob o pretexto de não provocar o estresse materno é questionável, transparecendo a intenção de preservar a crença materna na competência da medicina em ser capaz de proporcionar à mulher o ideal estético desejado para suas mamas, sem alterar a capacidade funcional das mesmas.

Considerando as limitações impostas pela mamoplastia, para prover o aleitamento, as mulheres reconstruíram a prática da amamentação como forma de estabelecer um vínculo com o filho e transmitir o amor materno. Assumem que estão presentes e interagindo com o filho nos momentos da oferta de mamadeira e consideram que a maternidade possui uma abrangência maior que a representada apenas ou primordialmente pela amamentação.

É possível compreender na vivência das mulheres que não foram capazes de manter a amamentação, em especial a exclusiva, e atribuem aos efeitos da cirurgia, um sofrimento associado à culpa e reiterado pela recriminação velada ou explícita que percebem em seu entorno. Assim, buscam justificar perante a censura social existente em relação à mulher que não 
amamenta, e é considerada culpada pelos danos emocionais e físicos à criança. Clamam pelo respeito as suas opções de vida.

Neste estudo, encontramos mulheres com disposição para amamentar e que tentaram implementar a amamentação a despeito de dificuldades e dúvidas. Baseando-se no modelo teórico que empregamos, é possível dizer que essas nutrizes também desenvolveram seu processo de amamentar de uma forma estimativa e avaliativa, contínua e cotidiana de suas condições de amamentar, atribuindo valor e significado à experiência de amamentação. Sobressai, para essas mulheres, o significado de benefício da amamentação para a criança, quando percebem que superaram as dificuldades iniciais e conseguiram manter o volume de leite suficiente para alimentar o filho. No entanto, a amamentação assume caráter de risco, diante da baixa produção de leite e do esforço materno em manter o ritmo de mamadas dioturnamente para o filho, fatores esses que assumidos também como risco ao bem estar materno, influenciaram na adoção de complemento ou no desmame.

Pareceu-nos, por meio dos dados obtidos que as dificuldades e a impossibilidade de amamentar foram pautadas efetivamente nas questões biológicas e estruturais da glândula mamária e não em questões culturais de valorização do corpo feminino, porém, o bem-estar materno, visto pela necessidade de sono e repouso da mãe, esteve presente como interferência na trajetória da amamentação.

Assim, é possível inferir que a crença e a crítica correntes na sociedade e entre os profissionais da área de saúde, de que a mulher com mamoplastia não deseja amamentar para não comprometer o resultado estético de suas mamas, obtido pela cirurgia, não se evidenciou, apesar de perceber-se que a meta de manter sua imagem corporal em padrões idealizados ainda permanece, projetando possibilidades de adotar o mesmo recurso no futuro. 
Os resultados obtidos por esta pesquisa nos remetem-nos à necessidade de aprofundar a questão da interface da amamentação com os resultados das mamoplastias em diversos âmbitos de sua abrangência, seja do ponto de vista estrutural e funcional mamário ao estudo dos significados maternos em relação ao seu corpo e ao desempenho de nutriz.

Este estudo alerta, para a necessidade de uma assistência voltada a essas mulheres com o objetivo de ajudá-las a minimizar seu grau de ansiedade em relação à repercussão da cirurgia no processo de aleitar, considerando que não é possível precisar a interferência cirúrgica e dos traços de ansiedade, na produção do leite.

Por outro lado, também se faz necessária a divulgação da forma com que as mulheres com mamoplastia, redutora e de aumento, vivenciam o processo de amamentação, para que possam estar melhor preparadas para a situação futura com menor grau de ansiedade e culpa. 


\section{REFERÊNCIAS}

Abla LEF. Qualidade de vida e auto-estima em pacientes submetidas à mastoplastia de aumento. [tese]. São Paulo (SP): Escola Paulista de Medicina da UNIFESP; 2002.

Aboudib JH Jr, Castro CC, Coelho RS, Cupello AM. Analysis of late results in postpregnancy mammoplasty. Ann Plast Surg 1991; 26(2):111-6.

Almeida JAG. Amamentação: um híbrido natureza-cultura. Rio de Janeiro: FIOCRUZ; 1999.

American Academy of Pediatrics. Committee on Drugs. The transfer of drugs and other chemicals into human milk. Pediatrics 2001; 108(3):776-89.

Arantes CIS. O fenômeno amamentação: uma proposta compreensiva. [tese]. Ribeirão Preto (SP): Escola de Enfermagem de Ribeirão Preto/USP; 1991.

Berens PD. Prenatal, intrapartum and postpartum support of the lactating mother. Pediatr Clin North Am 2001; 48(2):365-75.

Berlin CM. Silicone breast implants and breast-feeding. Pediatrics 1994; 94(4 Pt 1):547-9.

Black RF. Anatomy and function of the hypothalamus and pituitary in lactation In: Black RF, Jarman L, Simpson JB. The science of breastfeeding - lactation specialist self study series: module 3. Boston: Jones and Bartlett Publishers; 1997. p.29-51.

Blomqvist $\mathrm{L}$, Brandberg $\mathrm{Y}$. Three year follow-up on clinical symptoms and health-related quality of life after reduction mammaplasty. Plast Reconstr Surg [serial online] 2004; 114(1):49-54.

Available from: < htpp://gateway2.ovid.com/ovidweb.cgi> (30 set. 2004).

Bordo SR. O corpo e a reprodução da feminidade: uma apropriação feminista de Foucault. In: Jaggar AM, Bordo SR. Gênero, corpo, conhecimento. Rio de Janeiro: Rosa dos Tempos; 1997.

Cash TF, Duel LA, Perkins LL. Women's psychosocial outcome of breast augmentation with silicone gel-filled implants: a 2 year prospective study. Plast Reconstr Surg [serial online] 2002; 109(6):2112-21. Available from: <http:// gateway2.ovid.com/ovidweb.cgi> (10 jun. 2004).

Conselho Nacional de Saúde. Resolução n.196, de 10 de outubro de 1996. Diretrizes e normas reguladoras de pesquisas envolvendo seres humanos. [online]. Disponível em: <http://conselho.saude.gov.br/docs/resolucoes/reso196.doc> (15 out. 2004).

Ferreira MC. Evaluation of results in aesthetic plastic surgery: preliminary observations on mammaplasty. Plas Reconstr Surg [serial online] 2000; 106(7):1630-5. Available from: <http:/l gateway2.ovid.com/ovidweb.cgi > (30 set. 2004). 
Fine NA, Mustoe TA, Fenner G. Breast reconstruction In: Harris JR, Lippman ME, Morrow M and Osbone CK. Diseases of the breast. $2^{\text {nd }}$ ed. Philadelphia: Lippincott; 2000. p.561-575.

Franco T, editor. Princípios de cirurgia plástica. São Paulo: Atheneu; 2002.

Garbers S, Terry MB, Toniolo P. Accuracy of self-report of breast implants. Plast Reconstr Surg [serial online] 1998; 101(3):695-98. Available from: <http://gateway1.ovid.com/ovidweb.cgi> (29 jul. 2003).

Greenfield LJ, Oldham KT, Zelenock GB, Lillemoe KD, editors. Surgery: scientific principles and practice. $3^{\text {rd }}$ ed. Philadelphia: Lippincott; 2001.

Grey F. Métodos de coleta de dados. In: LoBiondo-Wood G, HaberJ. Pesquisa qualitativa em enfermagem: métodos, avaliação crítica e utilização. Trad. de Ivone Evangelista Cabral. $4^{a}$ ed. Rio de Janeiro: Guanabara Koogan; 2001. p.174-185.

Hurst NM. Lactation after augmentation mammoplasty. Obstet Gynecol 1996; 87(1):30-4.

Hurst NM. Breastfeeding after Breast augmentation. J Hum Lact 2003; 19(1):70-1.

Johansson AS, Wennborg H, Blomqvist L, Isacson D, Kylberg E. Breastfeeding after reduction mammaplasty and augmentation mammaplasty. Epidemiology [serial online] 2003;14(1):127-9. Available from: http://gateway1.ovid.com/ovidweb.cgi (14 jul. 2003).

Johnson CS, Preuss HS, Eriksson E. Plastic Surgery. In: Sabiston DC Jr, editor. Textbook of surgery: the biological basis of modern surgical practice.16 th $\mathrm{ed}$. Philadelphia: W. B. Saunders; 2001. p.1550-1569.

Jordan ME, Blum RWM. Should breast-feeding by women with silicone implants be recommended? Arch Pediatr Adolesc Med 1996; 150(8):880-1.

Klaus MH, Kennel JH, Klaus PH. Vínculo: construindo as bases para um apego seguro e para a independencia. Trad. de Maria Rita Hofmeister. Porto Alegre: Artes Médicas Sul; 2000.

Kopans BD. Imagin analysis of breast lesions. In: Harris JR, Lippman ME, Morrow M, Osbone CK. Diseases of the breast. $2^{\text {nd }}$ ed. Philadelphia: Lippincott; 2000.p.123-147.

Lefreve $F$, Lefevre AMC. O discurso do sujeito coletivo: um novo enforque em pesquisa qualitativa (desdobramentos). Porto Alegre: EDUCS; 2003.

Logothetis ML. Women's reports of breast implant problems and silicone-related illness. J Obstet Gynecol Neonatal Nurs 1995; 24(7):609-16. 
Marcus TM, Liehr PR. Abordagens de pesquisa qualitativa. In: LoBiondo-Wood G, Haber,J. Pesquisa qualitativa em enfermagem: métodos, avaliação crítica e utilização. $4^{\mathrm{a}}$ ed. Trad. de Ivone Evangelista Cabral. Rio de Janeiro: Guanabara Koogan; 2001. p.122-139.

Marshall DR, Callan PP, Nicholson W. Breastfeeding after reduction mammaplasty. Br J Plast Surg 1994; 47(3):167-9.

Masson SC. Representações sociais de mães sobre a chupeta. [tese]. São Paulo (SP): Escola de Enfermagem da USP; 2002.

Merighi MAB, Praça, NS. Abordagens teórico-metodológicas qualitativas: a vivência da mulher no período reprodutivo. Rio de Janeiro: Guanabara Koogan; 2003.

Minayo MCS. O desafio do conhecimento: pesquisa qualitativa em saúde. $7^{\text {a }}$ ed. São Paulo: Hucitec; 2000.

Mohrbacher N, Stock J. La Leche League international: the breastfeeding answer book. Schaumburg:[sn]; 1997.

Nakano, MAS. O aleitamento materno no cotidiano feminino. [tese]. Ribeirão Preto (SP): Escola de Enfermagem de Ribeirão Preto/USP; 1996.

Nakano MAS. As vivências da amamentação para um grupo de mulheres: nos limites de ser "0 copo para o filho" e de ser "o corpo para si". [tese]. Ribeirão Preto (SP): Escola de Enfermagem de Ribeirão Preto/USP; 2003.

Organización Panamericana de la Salud (OPAS). Organización Munidial de la Salud (OMS). Indicadores para elvaluar las praticas de lactancia materna: informe de uma reunión. Ginebra; 1991.

Ramos CV, Almeida JAG. Alegações maternas para o desmame: estudo qualitativo. J Pediatr [periódico online] 2003; 79(5):385-90. Disponível em: <http://jped.com.br> (28 maio 2005).

Reis MMF. Mulher: produto com data de validade. São Paulo: O Nome da Rosa; 2002.

Ribeiro SFM, Ferreira MC, Tuma Junior P, Bonamichi GT. Aspectos de personalidade e motivações de pacientes para mastoplastia. Rev Hosp Clin Fac Med S Paulo 1992; 47(6):290-4.

Rohrich RJ, Muzaffar AR. American Council on Science and Health. Silicone gel breast implants: Health and regulatory update 2000. [online]. New York; 2000. Disponível em:

$<$ http://www.freebooks4doctors.com/fb/english4.htm> (29.07.2003). 
Sarwer DB, Bartlett SP, Bucky LP, La Rossa D, Low DW, Pertschuk MJ et al. Bigger is not always better: body image dissatisfaction in breast reduction and breast augmentation patients. Plast Reconstr Surg 1998; 101(7):1956-61.

Sclnitt SJ, Connolly J. Pathology of Benign Breast Disorders. In: Harris JR, Lippman ME, Morrow M, Osbone CK. Diseases of the breast. $2^{\text {nd }}$ ed. Philadelphia: Lippincott; 2000. p.75-93.

Silva IA. Reflexões sobre a prática do aleitamento. Rev Esc Enferm USP 1996; 30(1):58-72.

Silva IA. Amamentar: uma questão de assumir riscos ou garantir benefícios. São Paulo: Robe; 1997.

Silva IA. Construindo perspectivas sobre a assistência em amamentação: um processo interacional. [tese]. São Paulo (SP): Escola de Enfermagem da USP; 1999.

Silva IA. Desvendando as faces da amamentação através da pesquisa qualitativa. Rev Bras Enferm 2000; 53(2):241-9.

Smith M, Kent K. Breast concerns and lifestyle of women. Clin Obstet Gynecol 2002; 45(4):112939.

Smeltzer SC, Bare BG. Brunner \& Suddarth: tratado de enfermagem médico cirúrgica. $9^{a}$ ed. Trad. de Isabel Cristina Fonseca da Cruz et al. Rio de Janeiro: Guanabara Koogan; 2002.

Thompson Z. Problemas das mamas e mamilos: como prevenir e tratar. In: Rego JD. Aleitamento materno: um guia para pais e familiares. São Paulo: Atheneu; 2002. p.83-101.

Vinha VHP. Projeto aleitamento materno: autocuidado com a mama puerperal. São Paulo: Sarvier/ FAPESP; 1994.

Young VL, Nemecek JR, Nemecek DA. The efficacy of breast augmentation: breast size increase, patient satisfaction and psychological effects. Plast Reconstr Surg 1994; 94(7):958-69. 


\section{ANEXO 1 \\ ROTEIRO DA ENTREVISTA}

Conte-me como tem sido a sua experiência de amamentação.

O que a motivou a amamentar?

Houve algum tipo de trauma nos mamilos?

O que você fez para cicatrizá-los?

Houve necessidade de introdução de complemento?

Como você fez o esquema de complementação?

Você necessitou que alguém a auxiliasse nesse período inicial?

Você teve alguma preocupação que a amamentação pudesse alterar o resultado conquistado com a cirurgia?

O que a levou a fazer a cirurgia?

Você ficou satisfeita com o resultado cirúrgico?

Você gostaria de falar algo mais da sua experiência de maternidade? 
ANEXO 2

Formulário de coleta de dados:

\section{CARACTERIZAÇÃO DAS MULHERES ENTREVISTADAS COM MAMOPLASTIA REDUTORA E DE AUMENTO}

\section{Dados maternos}

N. ${ }^{\circ}$ do prontuário: Nome: Idade: Profissão:

N. ${ }^{0}$ de Gestações: $\mathrm{N} .^{0}$ de paridade:. N. ${ }^{0}$ de Abortos:

Tipo de parto: ( ) cesárea ( ) normal ( ) fórceps

Amamentação anterior: ( ) sim tempo ( ) não ( ) sem informação

Tipo de cirurgia: ( ) implante mamário ( ) mamoplastia redutora

Tempo de cirurgia:............anos ( ) sem informação

Tipo de mamilo: ( ) protruso ( ) semiprotruso

( ) invertido ( )pseudoinvertido ( ) sem informação

Trauma mamilar: ( ) sim Tipo:. ( ) não ( ) sem informação

\section{Dados do RN}

Sexo: ( ) fem. ( ) masc. Idade Gestacional:.

Peso de nascimento: . .9

Peso na alta: Perda de peso:........g

Diagnóstico: Termo, Adequado para a Idade Gestacional ( )

Termo, Grande para a Idade Gestacional ( )

Termo, Pequeno para a Idade Gestacional ( )

$$
\text { Pré Termo（） Outros（ )............... }
$$

Amamentação em sala de parto: ( ) sim ( ) não

Introdução de complemento: ( ) sim ( ) não

Introduzido: ( ) $1^{0} \mathrm{dia}\left(\right.$ ) $2^{0} \mathrm{dia} \quad$ ( ) $3^{\circ} \mathrm{dia}\left(\right.$ ) $4^{0} \mathrm{dia}$

tipo: ..volume: $n^{\circ}$ de ofertas:........

Tempo de internação:...... dias 
ANEXO 3

AGENDAMENTO DAS ENTREVISTAS

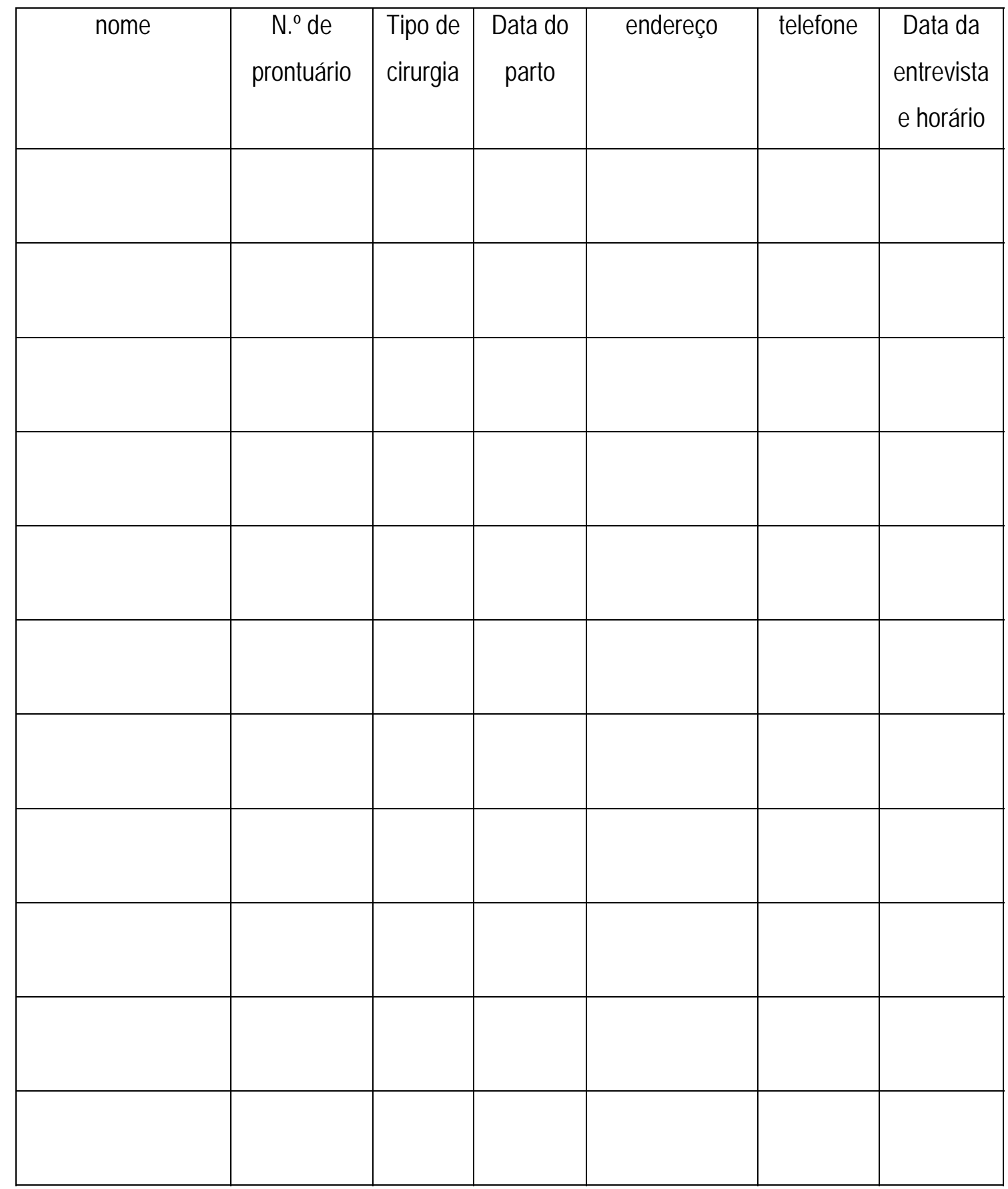




\section{ANEXO 4 \\ TERMO DE CONSENTIMENTO LIVRE E ESCLARECIDO}

Título da pesquisa: Amamentação na perspectiva das mulheres com mastoplastia de aumento e redutora (título provisório)

Convido a senhora a participar de um estudo que tem como objetivo compreender a experiência da amamentação em mulheres com cirurgias plásticas nas mamas, com prótese de mama ou com mamoplastia redutora.

A sua participação consiste em relatar sua experiência referente à amamentação após aproximadamente um mês do nascimento de seu filho. Essa entrevista será feita em sua residência ou por telefone, de acordo com sua conveniência.

Esta pesquisa não acarretará nenhum risco ou desconforto para a senhora e para seu filho. Não haverá despesas com a participação ou compensação financeira.

Durante o desenvolvimento do estudo, a senhora terá acesso para esclarecimento de dúvidas com a pesquisadora principal, Maria Fernanda Pellegrino da Silva Dornaus, coordenadora de enfermagem da Unidade Neonatal do Hospital Israelita Albert Einstein e dicente do curso de pós-graduação, nível mestrado, da Escola de Enfermagem da USP, residente na rua Deputado Laércio Corte, 1.250 apto. 161A, telefones 37434338 e 99500410 .

A sua participação na pesquisa pode ser interrompida quando desejar, sem qualquer prejuízo. Os dados obtidos na entrevista serão analisados juntamente com as das demais participantes deste estudo, sendo garantido o sigilo das identidades. Os resultados desta pesquisa serão divulgados em publicações científicas para auxiliar os profissionais a assistir as mulheres com cirurgias plásticas nas mamas em aleitamento materno.

\section{Autorização}

Considero ter sido adequadamente informada a respeito da pesquisa "Amamentação na perspectiva das mulheres com de mastoplastia de aumento e redutora" pela enfermeira Maria Fernanda Pellegrino da Silva Dornaus. Compreendo os objetivos e os procedimentos deste estudo. Estou ciente que a participação não envolve despesas e não há compensação econômica. Concordo em participar deste estudo voluntariamente e estou ciente que minha participação pode ser interrompida quando eu desejar, sem qualquer prejuízo.

Assinatura do participante do estudo 1 $\overline{\text { Assinatura da pesquisadora }}$

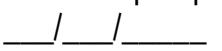




\section{ANEXO 5}

\section{DADOS MATERNOS E DO RECÉM-NASCIDO}

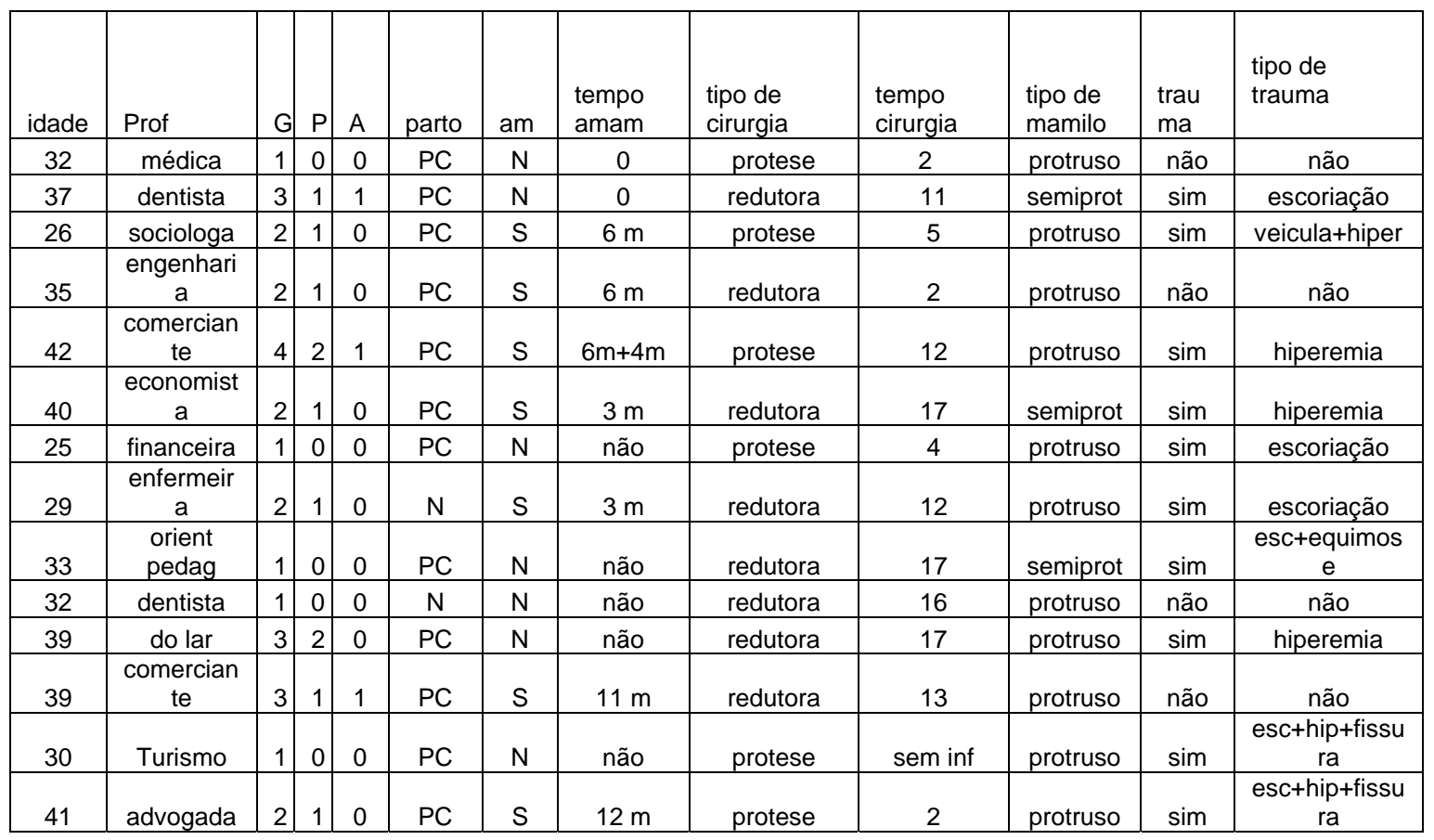

\begin{tabular}{|c|c|c|c|c|c|c|c|c|c|c|c|c|}
\hline sexo & IG & $\begin{array}{l}\text { peso de } \\
\text { nascimento }\end{array}$ & $\begin{array}{l}\text { peso na } \\
\text { alta }\end{array}$ & diagn & $\begin{array}{l}\text { amam } \\
\text { em sala }\end{array}$ & compl & dia & tipo & vol & $n^{\circ}$ oferta & $\begin{array}{l}\text { temp } \\
\text { inter }\end{array}$ & $\begin{array}{l}\text { Amamentação } \\
\text { após } \\
1^{\circ} \text { mes }\end{array}$ \\
\hline mas & 38 & 3350 & 3050 & TAIG & não & não & não & não & não & não & 5 & Desmame \\
\hline fem & 38 & 2275 & 2040 & TPIG & $\operatorname{sim}$ & não & não & não & não & não & 4 & Exclusivo \\
\hline mas & 38 & 3165 & 2850 & TAIG & não & não & não & não & não & não & 4 & Exclusivo \\
\hline fem & 39 & 3590 & 3260 & TAIG & não & não & não & não & não & não & 4 & aleitamento \\
\hline mas & 38 & 3210 & 3020 & TAIG & não & não & não & não & não & não & 4 & aleitamento \\
\hline mas & 39 & 3420 & 3190 & TAIG & não & não & não & não & não & não & 4 & aleitamento \\
\hline mas & 39 & 3390 & 3090 & TAIG & $\operatorname{sim}$ & $\operatorname{sim}$ & 4 & Nan & 30 & 7 & 5 & aleitamento \\
\hline fem & 37 & 2770 & 2520 & TAIG & $\operatorname{sim}$ & não & não & não & não & não & 4 & aleitamento \\
\hline fem & 38 & 2840 & 2710 & TAIG & $\operatorname{sim}$ & não & não & não & não & não & 5 & Exclusivo \\
\hline
\end{tabular}


